

\title{
FUENSALDAÑA Y LOS VIVERO. UN CONFLICTO ANTISEÑORIAL.
}

\author{
por \\ ALFONSO FRANCO SILVA \\ Universidad de Cádiz.
}

RESUMEN: En este trabajo se analiza un conflicto antiseñorial que se desarrolló en la villa de Fuensaldaña, próxima a Valladolid, y que tuvo como protagonistas a los vecinos de esa villa que lograron enfrentarse con éxito a las abusivas exigencias de los Vivero. El becho cierto es que la extorsión, los abusos, la violencia incluso, se daban con frecuencia en las villas sometidas al régimen señorial, sobre todo en aquellas que, a partir de la época Trastamara babian sido enajenadas del realengo y entregadas por la Corona a sujetos particulares que basta entonces no babian tenido vinculación alguna con ellas.

Palabras Clave: Castilla. Señorios. Conflictos. Violencia.

ABSTRACT: This work analysis an antinoble conflict took place in village of Fuensaldaña, near Valladolid, where the neighobours manged to succesfully confront the abusive demands of the Vivero. It is true to say that extorsion, abuse and even violence were common in villages under noble control, especially those lands that, since the Trastamara epogue, bad been handed over by the Crown to private owners who bad no prior connection to them.

KEY WORDS: Castile. Lordship. Conflicts. Violence.

La bibliografia sobre los conflictos antiseñoriales en el reino de Castilla, en el tránsito de la Edad Media a la Moderna, es ya bastante numerosa desde que, en 1975, Julio Valdeón escribiera su ya clásico libro sobre el tema '. La última entrega que conozco, bien documentada, con buena bibliografía y mejor analizada, nos la ha proporcionado Rosa $\mathrm{M}^{2}$ Montero Tejada ${ }^{2}$. Nos encontramos, por tanto, ante un tema, que necesita ya de una nueva sistematización y de un

1 Los conflictos señoriales en el reino de Castilla en los siglos XIV y XV, Madrid, 1975.

2 "Violencia y abusos en los señorios del linaje Mantique a fnes de la Edad Median, En la España Medieval, 20 (1997), págs. 339-377. 
estudio riguroso que analice todos estos episodios de manera conjunta y se interpreten de forma correcta situándolos en su contexto histórico así como las causas, ciertamente complejas, que los explican. A este respecto pretendo presentar en este trabajo un conflicto de esta naturaleza que se desarrolló en la villa de Fuensaldaña, próxima a Valladolid, y que tuvo como protagonistas a los vecinos de esa villa que lograron enfrentarse con éxito a las abusivas exigencias de los Vivero. El material que me ha servido para este objetivo se encuentra en el Archivo Ducal de Alburquerque ${ }^{3}$.

\section{LOS DOMINIOS DE LOS VIVERO}

Hasta el año 1422 el lugar de Fuensaldaña pertenecía a los dominios del merino mayor de Asturias, Diego Fernández de Quiñones ${ }^{4}$. En ese año pasó a poder de Juan Quijada, señor de Villagarcía, que le confiscó la villa por deudas que Quiñones no le había satisfecho. Por poco tiempo, sin embargo, pues pronto se deshizo de él para venderlo por $14.000 \mathrm{mrs}$. a Sancho Fernández de León, escribano de cámara del rey, y su contador ${ }^{5}$. El 21 de octubre de 1422 se desplazó a Fuensaldaña el procurador Fernán García de Cordera que, en nombre del contador Fernández de León, procedió a tomar posesión de ese lugar ${ }^{6}$. Este acto simbólico de toma de posesión se recogió en un interesante documento que, para el objetivo que pretendo, va tener una gran importancia mas adelante, cuando los vasallos del lugar hagan valer sus derechos ante las excesivas imposiciones de sus señores. En efecto, el procurador Fernán García tomó posesión de la propiedad eminente de los suelos sobre los que se levantaban las casas de los vecinos de Fuensaldaña, y solamente de ellos. En virtud de esa toma de posesión, los vecinos se comprometieron a residir en esas casas «según que habian morado fasta aquí asy como vasallos del dicho Sancho Fernandes y que se obligaban por sí y por sus bienes muebles e rayçes avidos e por aver para pagarle todos los derechos, usos y fueros, sernas y yantares que acostumbraban a pagar a Juan Quijada y a los señozes anteriores». Es importante recoger esta idea —el señor solo toma posesión de la propiedad eminente de los suelos edificados en el lugar- porque mas tarde será uno de los factores decisivos para la victoria de los vasallos sobre el señor.

Unos años más tarde, y tras la derrota en 1430 de los infantes de Aragón, Juan II confisca los bienes del contador Fernández de León, y entrega Fuensaldaña a Martin de Luna, un hermano del todopoderoso privado Alvaro de Luna, que en ese momento había salido fortalecido en la pugna con los aragoneses ${ }^{7}$ Este lugar pasaba así de un señor a otro, como muchas otras villas en

3 En adelante $A . C . D A . \mathrm{n}^{\circ} 186$, Leg. $5, \mathrm{n}^{\circ} 6$.

4 A.C.D.A. $\mathrm{N}^{\mathrm{a}} 185$, Leg. $2, \mathrm{n}^{\circ} 1$.

5 Ibidem.

6 Ibidem.

7 Ibidem.

Hispania, LIX/3, núm. 203 (1999) 823-855 
esta época, hasta que un ambicioso personaje, el Contador Mayor Alonso Pérez de Vivero, que por entonces era un protegido del propio don Alvaro, y estaba intentando crearse unos dominios propios, decidió hincarle el diente y hacerse con él. No paró hasta conseguirlo. Primero se hizo con los derechos que a ese lugar pretendía tener Diego Sarmiento, Adelantado Mayor de Galicia, que se los concedió generosamente, en 1435, por los muchos servicios que el Contador y su padre habian hecho a los Sarmiento ${ }^{8}$. Al año siguiente logró que su protector, el Condestable Luna, obligase a su hermano Martín a vendetle la villa por $70.000 \mathrm{mrs}$. De esta manera Fuensaldaña pasaba a poder de Pérez de Vivero ${ }^{10}$.

La compra de Fuensaldaña nada tenía de caprichosa. Antes bien, constituía una pieza fundamental para el objetivo que pretendía el Contador Mayor, que no era otro que la creación de un patrimonio propio, lo más sólido y homogéneo posible, en tierras próximas a Valladolid, villa en la que residía junto a la corte de Juan II, y en la que ya disponía de bienes. No lo conseguirá del todo, pero pudo hacerse con numerosas casas, tierras y lugares cercanos. Más tarde conseguiría adquirir todo un conjunto numeroso de propiedades: algunos lugares cercanos a la ciudad de Avila - Castronuevo, Naharrillos-y otras heredades y bienes en tierras de Salamanca, Medina del Campo, Segovia, Toledo, Córdoba y Andújar ${ }^{11}$. Sin embargo, la inversión más importante que hizo fue la compra en 1450 , tres años antes de motir, de las encomiendas que la orden de Alcántara poseía en Castilla ${ }^{12}$. En primer lugar se hizo con la encomienda de Barcial de la Loma, pueblo también cercano a Valladolid, de la que formaba parte esa villa que venía a ser la capital de la encomienda de Castilla, el lugar de Vecilla, el lugar de Valdesandines, el lugar de Villaester, y toda una serie de heredades en la villa de Tisdraque -que pertenecía a Pedro Girón, maestre de la orden de Calatrava - Villalar - que era de la orden de Santiago-y el lugar de Pedrosa que pertenecía a la jurisdicción de Toro. Así mismo la orden poseía también otros bienes que se administraban desde esa encomienda: los portazgos de la Puente de Orbigo, Carrizo y la Laguna de Negrillos, lugares los tres, que pertenecían a la jurisdicción de los herederos de Diego Fernández de Quiñones, las tercias de la villa de Benavente, y algunos otros mas. Por todo este conjunto de bienes Vivero ofreció, en 1449, a la orden un juro de heredad que se situaría en las rentas reales de aquellas villas que el maestre y los frailes quisiesen. La orden decidió considerar el ofrecimiento, y a tal fin se reunió en capítulo en Tordesillas, en una sala de los palacios reales de esa villa, estando

8 Ibidem, Leg. $2, \mathrm{n}^{\circ} 1$.

9) Ibidem.

10 El 20 de septiembre de 1439 Juan II le confirmaba en la posesión de la villa. A.C.D.A., $N^{\circ} 185$, Leg. $2, n^{0} 2$.

11 Franco Silvh, Alfonso, La Fortuna y el poder. Estudios sobre las bases económicas de la aristocracia castellana, Cádiz, Publicaciones de la Universidad, 1996, págs. 420-424.

${ }_{12}$ A.C.D.A. N $\mathrm{N}^{\circ} 191, \mathrm{Leg}, 11, \mathrm{n}^{\circ} 17$. Se trata de varios documentos insertos en la toma de posesión de Barcial de la Loma. 
presentes el maestre, don Gutierre de Sotomayor, y todos los comendadores. El capítulo tuvo que celebrarse en esa villa porque en aquel momento el maestre y una gran parte de los comendadores se encontraban en ella al servicio de Juan II ${ }^{13}$. Allí se acordó que dos comendadores, Rodrigo de Medina y Lope de la Cadena, se desplazasen a los lugares de la encomienda de Castilla para conocer in situ qué renta les proporcionaba. Se supo que eran $30.000 \mathrm{mrs}$. y que esa cantidad llevaban más de veinte años sin cobrarla, y que tanto los lugares como las heredades que en ella se encontraban estaban «derramados», algunos de ellos se hallaban ocupados por los señores comarcanos, e incluso por otras ciudades y villas. Este informe fue determinante para que la orden comprendiese que la operación que les ofrecía el Contador Mayor les era mucho más rentable y provechosa que su mantenimiento. Así pues, considerando todo esto, el maestre volvió a llamar a capítulo, a la hora de misas mayores, en el convento de Santa Clara, en concreto en la capilla de Fernán López de Saldaña. Alli recibieron al procurador de Pérez de Vivero, Lope Cabelas, vecino de Zamora, que llevaba poderes de su señor para fíniquitar el negocio. Después comenzaron a deliberar sobre las ventajas e inconvenientes que podrian venirle si daban el visto bueno a la operación. Todos estuvieron de acuerdo en que había que hacerlo, porque, además de las razones ya expuestas, la encomienda se hallaba bastante excéntrica de los dominios principales de la orden, muy alejada de Alcántara, incluso, dentro de la propia encomienda, los lugares estaban lejos unos de otros, mezclados con vasallos de otros señores, por consiguiente no podía administrarse y regirse bien, ni siquiera podían ser defendidos ante las agresiones de los comarcanos, la posesión les era por tanto disputada casi constantemente, eran muy costosos de mantener, rentaban muy poco, sus casas se caían y los lugares se despoblaban. La oferta era además muy buena, porque permitía a la orden disponer de rentas fijas y seguras en villas y lugares que estuviesen en sus tierras, en concreto en Coria y en la propia Alcántara. Tras una serie de "fablas e pláticas» entre ellos, acerca del negocio propuesto, se procedió a la votación, primero lo hizo el maestre e inmediatamente después los demás. Todos estuvieron de acuerdo, en consecuencia el maestre les emplazó a otra reunión, que se celebraría al día siguiente, 24 de octubre de 1449, en el mismo lugar y a la misma hora "para haber sobre ello otro solemne e deligente tratado e acatar el dicho contratom. A la mañana siguiente todos, comenzando por el maestre, se reafirmaron en sus votos, y en consecuencia procedieron a ratificar el trueque de esos lugares por un juro de 400 florines de oro-que eran $28.000 \mathrm{mrs}$, a razón de $70 \mathrm{mrs}$. el florín- situados en las alcabalas de varios lugares de la villa de Arévalo (Lomo Viejo, Juan Román, Castellanos, San Cristóbal, Berbel, Bañuelos, Velasco Nuño, Cienlabajos, Montelo de la Vega, Fernal y Moraleja de Matacabras), otto de $22.680 \mathrm{mrs}$. situados en las alcabalas de pan, vino, carnicerías, en las del haber del peso y en

13 Llegaron a temer incluso que la operación de compra no se llevase a efecto «por los grandes escándalos y bollicios del reino». Tenían prisa por finalizar este negocio porque de no hacerse le vendrian graves daños, por eso se vieron obligados a reunirse en Tordesillas.

Hispania, LIX/3, núm. 203 (1999) 823-855 
las de la leña de la villa de Arévalo. En total, la orden tecibió $56.680 \mathrm{mrs}$. de juro, que el monarca había concedido a Pérez de Viveto con la facultad de poder vendetlos o traspasarlos a quien quisiete. Tras firmar el contrato de cesión, el maestre y los comendadores juraron y prometieron al Contador Mayor que jamás le quitarían esa encomienda.

Vivero conseguía así hacerse con la encomienda de Castilla, pero la orden seguía reteniendo, fuera de su comarca, otras dos más la de Xema o Jema en el obispado de Zamora y la de lavandera en el reino de Galicia. El Contador Mayor, para ampliar y redondear sus posesiones, logró también que la Orden le cediese la encomienda zamorana por otro juro de $30.000 \mathrm{mrs}$. situados en las alcabalas de la villa de Alcántara, tal como habían deseado el maestre y los comendadores. Por último, y tras la aprobación del concierto por Juan II el 28 de octubre de 1450, Vivero envió a Cristóbal de Valladolid a Barcial de la Loma para que, en su nombre, tomase posesión de la villa ${ }^{14}$. En total el Contador Mayor había desembolsado por la compra de ambas encomiendas la cantidad de $80.000 \mathrm{mrs}$.

Dos años más tarde, Pérez de Vivero solicitó a Juan II que le concediese licencia para fundar un mayorazgo con los bienes que había adquirido. El permiso real le llegó el 2 de diciembre de 1452, y pocos días más tarde, el 14 de ese mismo mes, procedia a crear un mayorazgo en favor de su hijo primogénito Juan de Vivero ${ }^{15}$. En ese documento, Alfonso Pérez de Viviero explicaba los motivos que le habían llevado a crear mayorazgo: se declaraba shumill fechura y crianza del reym, conocedor de los beneficios y gracias que ha recibido y recibe de Juan II, y de su alta magnificencia y liberalidad, cree, por tanto, que debe vincular sus bienes para que así sus descendientes puedan servir mejot al monarca y a sus herederos, y para que de esta manera su hijo y su parentela puedan vivir más honrados. Tras esta solemne declaración en la que se reconoce deu-

14 La toma de posesión de esa villa tiene un gran interés. En primer lugar, tras el reconocimiento de señorío por parte de los dos alcaldes ordinarios, el apoderado de Vivero prolibió la caza en todo el término de ese lugar bajo multa de $100 \mathrm{mrs}$. a los infractores, también prohibió el uso de las armas bajo pena de perderlas, puso horca para que en ella fuesen ahorcados aquellos que fuesen condenados; luego fue a varias casas, echó a sus habitantes y después los volvió a entrar en señal de posesión de su suelo que pertenecía al señor, anduvo con la vara de la justicia por diversas partes del lugar, finalmente se dirigió a las puertas de la villa las cerró y las volvió a abrir en señal de posesión y entregó las llaves a un vecino. Más tarde fue a la iglesia de San Miguel y en presencia del cura tomó posesión de ella, de su patronazgo y de sus rentas, tañó la campana, aderezó los altares, las sábanas y ornamentos, tomó un libro en la mano, lo abrió, leyó en él y luego lo cerró, echó al cura y lo volvió a entrar, luego le preguntó si se habian recogido los diezmos y ofrendas, el sacerdote le respondió que en ese momento no había pero que cuando los hubiese se los entregaria. Todo ello en señal de posesión en nombre de Vivero. Por último pidió cuentas al mayordomo del concejo si debía alguna cantidad, y este le entregó 300 mrs. Sobre este interesante tema el mejor y el más completo trabajo que se ha hecho hasta ahora es el de BECEIRO PITA, Isabel, (El escrito, la palabra y el gesto en las tomas de posesión senoriales», Studia Historica, 12 (1994), págs. 53-82.

15 A.C.D.A. No 186, Leg. $5, \mathrm{n}^{\circ} 4$. 
dor de Juan II, y en la que no menciona para nada al verdadero protector, don Alvaro de Luna, sin cuya intervención, como he puesto de manifiesto en otro trabajo anterior, nunca hubiese consolidado su posición en la Corte, $y$, desde luego, jamás hubiese conseguido un patrimonio propio, Pérez de Vivero pasa a enumetar las villas y bienes que desea que formen parte de ese mayorazgo ${ }^{16}$. Esas villas eran las siguientes:

Viveiro, en el reino de Galicia (provincia de Lugo), con el alfolí de la sal y el diezmo de la mar ${ }^{17}$. A esta villa se incorporaban sus feligresias: Galdo, Juances, San Esteban do Vale, San Miguel de Asnegradas, todas ellas situadas en las riberas del río Sor, junto con los castillos de Villaton y Samariego, con todos sus términos, vasallos, jurisdicción, etc.

- las pueblas lucenses de Burón y Navia

- el lugar de Fuensaldaña con su fortaleza

- el lugar de Barcial de la Loma

- el lugar de Vecilla

- el lugar de Valdesandines, en el Páramo, cerca de la Puente de Orvigo

- las casas principales que poseía en Valladolid, en la puerta de San Pedro, con su huerto, que lindan tres partes de ellas con las calles públicas y la otra parte con la muralla de la villa

- otta casa pequeña frente a las anteriores, a la otra parte de la puerta, también con huerto

- las aceñas que están junto al Duero, en término de Valladolid, cerca de Ferrera

- la huerta que se halla cerca de La iglesia de Valiadolid, junto al nío Esgueva

- un juro de 20.000 mrs. situado en las alcabalas de la carne y del vino de Salamanca, juro este que Juan II le había concedido por los servicios que le había prestado en el cerco sobre la villa de Atienza

- otro juro de $18.000 \mathrm{mrs}$. sobre las rentas reales de Zamora, de ellos 12.000 en las alcabalas del pescado y 6.000 en las de la fruta

16 Es casi seguro que en ese momento Vivero intentaba ya distanciarse de don Alvaro de Luna, quizá temiendo por la pérdida de su posición ante la próxima e inevitable caída del Condestable, Franco SiLVA, Alfonso, op.cit., págs. 408-409.

17 La villa de Vivero - $\rightarrow$ Viveiro como se denomina en la actualidad-pertenecía al príncipe de Asturias -futuro Enrique IV - desde el año 1440 en que su padre, Juan Il, se la había concedido, junto con Cáceres, como recompensa por la pérdida de Trujillo, Crónica de Juan II, Tomo LXVIII de la B.A.E., Madrid, 1953, año 1440, cap. XXI, p. 569. Unos años más tarde, en 1451, el Contador Mayor logró hacerse con ella mediante un trueque con el príncipe, éste le daba Viveiro y Alfonso Pérez le entregaba las villas de Jorquera, Alcalá del Rio Jucar, Ves y la Roda, villas estas que había recibido unos años antes de Juan II. Tras el trueque se hallaba, como siempre, el privado del heredero al trono, Juan Pacheco, que trataba de incorporar estas últimas villas a su recién adquirido marquesado de Villena. El trueque en Archivo Ducal de Frías hoy en el Archivo de la Sección Nobleza de Toledo, Catálogo Antiguo, Leg. 5, números 32 y 33 y en A.C.DA., $\mathrm{N}^{\circ} 191, \mathrm{Leg} .11, \mathrm{n}^{\circ} 9$, Franco Silvn, Alfonso, «Jorquera y Alcalá del Río Júcat a funes del Medievo. Dos villas del marquesado de Villenan, Miscelanea Medieval Murciana, Vol. XVIII (1993-94), págs. 24 a 29.

Ilipqania, LIX/3, nủm 203 (1999) 823-855 
- otro juro de $24.000 \mathrm{mrs}$. situados en ciertos lugares del infantado de Valladolid: 6.000 en las alcabalas de Olivares, 7.000 en las de Cabezón, 5.000 en las de Wamba, 1.500 en las de Renedo, 1.000 en las de Ovinos, 1.000 en las de Santovenia y 1.500 en Ciguiñuelas 18 .

Todos estos dominios formarían parte del mayorazgo, que debería transmitirse siempre por vía masculina en la persona y descendientes de su hijo mayor Juan de Vivero. Las condiciones que impone para heredarlo son las habituales en este tipo de institución: serían siempre bienes inalienables, no sujetos a las leyes del mercado, es decir no podrín venderse ni cambiarse jamás, porque como afirma el monarca en la carta de licencia «sí esos bienes se dividiesen en muchas partes y entre muchos herederos yo no podría ser tan bien servido dellos, ni los reyes que me sucedan, y como la virtud unida sea más fuerte y mas eficaz que la divisa y derramada y repartida por muchos, y asi estén unidos para que la memoria de vuestra casa, linaje y solar de Viveto permanezca, y vuestros hijos y casa sean mejor acatados y puedan servir mejor a mi y a los reyes que me suçedany. Si la sucesión de Juan fallara por falta de descendientes, el Contador Mayor llama a heredar sucesivamente a la parentela de sus tres restantes hijos, Lope, Francisco y Alfonso de Vivero. Sólo en el caso hipotético de que faltaran los varones, el fundador llama a la sucesión a las hembras, en primer lugar a su hija Aldonza, casada con el conde de Osorio Gabriel Manrique, y en defecto de esta a su otra hija Isabel, y si estas carecen de descendencia las llamadas a heredar serian sus tres últimas hijas, Inés, María y Catalina. De todos estos herederos, Pérez de Vivero sólo excluye a su hijo Alfonso - aunque no a sus descendientes - «por causa de las enfermedades que Dios le quiso dar, por ello no es hábil, ni capaz para sostener, tegir, ni administrar el mayorazgo, ni, por consiguiente, poder servir al reym. Todo fundador de mayorazgo solía siempre prever la posible desaparición total de sus hijos y descendientes. Pérez de Vivero no constituye una excepción a este respecto, y así, ante tal eventualidad, dispone que en ese caso el mayorazgo lo heredase su hermano Pedro de Viveto, y en defecto de éste y de su descendencia su sobrino Alfonso de Vivero, hijo de su hermana Teresa Rodríguez y si también este falla llama a la sucesión a otros dos sobrinos, Vasco de Vivero, hijo de su hermana María López, y Rodrigo de Vivero, hijo de su tercera hermana Mariana Pérez. Y si estos parientes también fallecen sin descendencia, el Contador Mayor, para evitar que el mayorazgo saliese definitivamente de su familia o desapareciese, llama a sucederle al pariente más próximo de su linaje, y si hay dos de ellos iguales o más en grado, que lo herede el que «cupiere por suette que entre si echen para evitar contiendas», y si alguno de ellos es clérigo de orden sacra o religioso profeso «que sea avido como si fuere muerto naturalmente y lo herede el siguiente en ordens. Excluye a los clérigos, pero no a los que no siendo de orden sacra tuviesen beneficios eclesiásticos, siempre que renunciasen a estos últimos. También contempla entre sus herederos a miembros de las ordenes militares, siempre, desde

18 Estos juros y los restantes fueton concedidos a Vivero por Juan II el 10 de noviembre de 1447. A.C.DA., No 184, Leg. $1, \mathrm{n}^{\circ} 3$.

Hitpania, LIX/3, num. 203 (1999) 823.855 
luego, que contrajesen matrimonio. Cualquiera que heredase el mayorazgo, fuese descendiente directo o pariente lejano, quedaba obligado a llevar el apellido de Vivero y sus armas de ortiguera que consistían en un escudo en campo colorado en el que se encontraban tres rosas pardillas en agua, y de cada punta de ellas salía un ramo de ortigas verdes con unas hojas. De todas maneras permite al sucesor que pueda poner en las orladuras el escudo de otro linaje, pero eso sí siempre que sus propias armas estén en el centro como principales, porque si no lo hace de esta forma, transcurrido un plazo de seis meses para que lo enmiende tal como él lo dispone, perdería el mayorazgo ${ }^{1 \%}$.

Pocos meses después, el viernes santo de 1453, Alfonso Pérez de Vivero perdia la vida a manos del que había sido su gran protector, Alvaro de Luna. Los acontecimientos que precedieron al asesinato del Contador Mayor, la forma de eliminarle y los hechos posteriores han sido estudiados por quien esto escribe hace ya algunos años ${ }^{20}$. El Condestable no pudo perdonar a su vasallo que traicionara su confianza, sumándose a la conjura nobiliaria dirigida por el conde de Plasencia, don Alvato de Estúñiga. Su traición significó su sentencia de muerte. Dos hombres fieles a don Alvaro, el secretario Fernando de Ribadeneira y Juan de Luna, le arrojaron al vacío desde una torre que se hallaba en la propia posada del Condestable ${ }^{21}$. La traición de Vivero le ocasionó su propia ruina, pero al mismo tiempo, por paradójico que parezca, logró conseguir su principal objetivo, pues don Alvaro fue degollado, por orden de Juan II, pocos días después del asesinato 22.

Tal como disponían las cláusulas sucesorias del mayorazgo, el heredero del mismo, su hijo Juan de Vivero, que más tarde ejercería también el mismo oficio del padre durante buena parte del reinado de Enrique IV, debería tomar posesión de sus bienes tras su muerte. Sin embargo no ocurrió así, pues, al ser menor de edad, su madre, Inés de Guzmán tuvo que encargarse de su tutoría y, por tanto, del gobierno y administración del patrimonio ${ }^{23}$. El Contador Mayor dejaba viuda y nueve hijos, todos ellos menores de edad ${ }^{24}$. El primogénito Juan recibía el oficio de su padre y heredaba el mayorazgo. Los restantes bienes que aparecen en un inventario, que fue publicado por mí hace ya algunos años, se repartieron a partes iguales entre los hermanos, una vez que se dedujeron aquellos que en concepto de gananciales correspondían a la viuda, aproximadamente la mitad del total ${ }^{25}$.

19 La reproducción de estos escudos en CoOpin, Edward, Castillos Señoriales de Castilla de los siglos $X V$ y XVI, Madrid, 1980, Tomo I, págs. 423-424.

20. La Fortuna y el Poder, págs. 411-412.

21 Ibidem.

22 Tbidem, págs. 412-413.

23 A.C.D.A. N 191 , Leg. $11,1^{\circ} 14$

24 En el inventario de bienes de 1453 se menciona a un hijo liamado Gil González, que sin embargo no figura citado en el documento de fundación de mayorazgo, Franco SiLva, A., La Fortuna y el Poder, pág. 414.

25 Ibidem, pág. 414 y sigs.

Hiptunia, LIX/3, núm 203 (1999) 823-855 
La fortuna que había logrado acumular Vivero, desde su privilegiada atalaya de Contador Mayor, siempre a la sombra protectora de don Alvaro de Luna, era bastante importante. La mayor parte de ella, es decir el patrimonio que formaba parte del mayorazgo creado en 1452, pasaba a poder de su hijo Juan, que heredaba así un enclave territorial importante en tierras de Lugo, principalmente la villa de Viveiro y sus feligresias, y un conjunto disperso de pueblos y aldeas situados en diversos lugares, pero fundamentalmente en áreas próximas a Valladolid, siendo Fuensaldaña y Bercial de la Loma las dos villas más importantes.

Mientras vivió Juan de Vivero el mayorazgo de su padre no sufrió en su composición modificación alguna. Su desaparición fue el pretexto que utilizaron los Reyes Católicos para recuperar Viveiro, una villa que había formado parte desde siempre de la Corona, y a la que no estaban dispuestos a renunciar por hallarse en una excelente posición como puerto en el centro de una ría que, además de disponer de un importante alfoli de la sal, percibía también jugosos beneficios por los diezmos de la mar. En 1484, Isabel y Fernando pactaron con los Vivero la entrega de esa villa a cambio de una serie de juros de heredad y la concesión del título de vizconde de Altamira a don Alonso Pérez de Vivero, sucesor de don Juan ${ }^{26}$. El primer juro de $34.954 \mathrm{mrs}$. en las alcabalas de Palencia lo despachaton los Reyes Católicos el 12 de diciembre de 1484, al año siguiente le concedieron otro de $15.000 \mathrm{mrs}$. sobre las alcabalas de Sevilla y Jerez de la Frontera, en 1486 otro de $12.833 \mathrm{mrs}$. en las alcabalas de Valladolid, y finalmente en 1490 un juro de 500 quintales de aceite -en total 5.000 arrobassituados en el diezmo de la ciudad de Sevilla. En total los juros sumaron la cantidad de $62.787 \mathrm{mrs}$ y 500 quintales de aceite.

De grado o por fuerza, los Vivero se vieron privados de la que, hasta ese momento, había sido la villa más importante de sus dominios, y sin lugar a dudas la cuna del linaje. A partir de entonces sería Fuensaldaña la perla principal de sus estados, y sobre ella se iban a volcar los titulares del señorío, pero eso sí, de forma negativa, pues al perder la villa lucense, que había sido la principal fuente de sus ingresos, comenzaron a exigir a sus restantes vasallos, y entre ellos a los vecinos de Fuensaldaña, nuevas imposiciones y tributos que hasta entonces nunca habían pagado, y lo que era aún más importante pronto se comprobó que no estaban dispuestos a tolerarlo.

\section{EL CONFLICTO}

Hasta comienzos del siglo XVI, los señores de Fuensaldaña percibían de sus vecinos cada año 200 cargas de pan, 50 carretadas de paja y 100 gallinas. Estas imposiciones habían sido el resultado de un pacto entre los Vivero y el concejo de la villa. En virtud de ese acuerdo los vecinos entregaban esas contribuciones y a cambio los señores renunciaban a exigir cualquier otra modali-

26. Justamente en ese año fallecia don Juan de Vivero. La entrega de Viveiro a los Reyes Católicos en A.C.D.A. N 154, Leg. $1, \mathrm{n}^{\circ} 3$.

Hi.pania, L1X/3, núm. 203 (1999) 823-855 
dad de prestación. Pronto sin embargo, las cosas cambiaron en perjuicio de la villa. El señor empezó a exigir nuevas imposiciones que los vecinos jamás habían pagado. El concejo fue soportando, con paciencia y a duras penas, una situación que cada vez se iba tornando más insoportable, porque las demandas señoriales iban en aumento. En un primer momento el concejo trató de evitar el conflicto apelando a la persona del vizconde e intentando llegar a un nuevo acuerdo con él, pero éste lo rechazó sin contemplaciones. No les quedó entonces más remedio, ante la negativa señorial, que ir a juicio, aún sabiendo a lo que se exponían: los pleitos eran largos y muy costosos, la persona a la que se enfrentaban era caballero poderoso, ellos eran sus vasallos, el señor ejercía la jurisdicción sobre la villa y temían además que sus parientes, criados o allegados les persiguiesen y les hiciesen daño en sus personas y haciendas. De todas maneras, ante la gravedad de la situación, y viendo que por la via del pacto nada se había conseguido, el concejo de Fuensaldaña decidió con todas las consecuencias embarcarse en una demanda judicial contra los Vivero, y así, el 30 de julio de 1516, nombró procurador para tal finalidad a Juan Gallego, un vecino de la villa. Mientras tanto, había fallecido el señor de la villa, Alonso Pérez de Vivero, y le había sucedido su hijo Juan que, al ser mayor de 14 años pero menor de 25, tenía necesidad de contar con un procurador para seguir pleitos, y a tal fin nombró a Antonio de Medina, procurador de causas en la corte y chancillería real, que se comprometió a aceptar el cargo, obligando para ello, por juramento, a su persona y a todos sus bienes muebles y raices ${ }^{27}$.

¿Cuál era el contenido de la demanda? o dicho de otra manera ccuáles eran esas nuevas imposiciones que los señores les exigían?. La tabla de reivindicaciones por parte del concejo de Fuensaldaña era muy amplia. En síntesis eran las siguientes:

a) El señor pretendía cobrar las multas que se imponían por los guardas de la villa cuando los ganados penetraban en sus términos. El concejo sostenía que esos términos le pertenecían, y por tanto era a él a quien se deberían pagar esas penas.

b) El vizconde, además de exigirles una nueva contribución de $1.000 \mathrm{mrs}$. anuales, pretendía que las cargas de trigo, que todos los años debía entregarle la villa, fuesen transportadas a su residencia de Valladolid a costa del pueblo.

c) Les demandaba el uso de los pastos, y pretendia quedarse con los provechos de los molates y canteras cuando todo ello, al formar parte de los términos del concejo, le pertenecían al mismo.

d) El vizconde le había ocupado también una parte del término, la llamada Cuesta del Escaño, en la que criaba conejos, que provocaban graves daños ya que destruían los panes que se hallaban sembrados en la villa.

e) Prohibía así mismo el ejercicio de la caza e imponía multas a quien lo hiciese, cuando esta actividad había sido siempre del común.

27 Según Cooper don Alonso Pérez de Vivero había fallecido en 1509 , op.cit., Tomo I, pág. 424.

ILipania, LIX/3, núm. 203 (1999) 823-855 
f) A fin de conseguir más paja de la que deberían darle cada año, el señor había mandado que se hiciese cesto, con el que se midiesen las 50 carretadas, exigiendo que cada carretada tuviese 50 cestos para así poder disponer de más cantidad. La costumbre era dar esa paja por el día de San Antolín, el vizconde la pretendía ahora antes de esa fecha.

g) Les obligaba a darles huéspedes y ropa, sin que tuviesen obligación para ello.

h) Incumplía sistemáticamente las ordenanzas de la villa que prohibían a sus ganados pacer en las dehesas, prados y rastrojos, impidiendo hacerlo a los ganados de los vecinos.

i) Apremiaba a los vecinos a que le diesen bestias para su servicio, cuando no tenían obligación alguna de hacerlo.

j) De poco tiempo acá se había hecho construir paza su disfrute exclusivo un estanque, junto a la única fuente que abastecía a la villa, con lo que recibían muy grave daño, porque no les había quedado agua para beber, salvo la de algunos pozos.

k) De tiempo inmemorial, los vecinos de Fuensaldaña gozaban del privilegio de elegir sus propios oficiales concejiles, el señor ahora había usurpado estc derecho y procedía a elegirlos de forma arbitraria, ya que nombraba a quien quería, aunque no fuese suficiente ni hábil para la gobernación de la villa.

l) Les obligaba a trabajar en sus propias tierras, sin pagarles por su trabajo y castigando con la prisión a quien se negaba.

m) Poseía una huerta abierta por muchas partes, y si entraban en ella los ganados de los vecinos les gravaba con grandes y penosas multas.

n) les imponía la prestación de hacer velas, cuando la villa jamás había tenido esa obligación, salvo en tiempos ya pasados de mucha necesidad.

Eran por tanto muy numerosos los agravios. $Y$ sin embargo la respuesta del procurador de los Vivero consistió en negar todas esas demandas, nada de imposiciones nuevas, todo lo que exigía lo hacía por derecho ya que era señor jurisdiccional de la villa. Por consiguiente desestimaba la demanda, no procedía de ninguna manera upor ser como era mal formadas, y la relación que en ella aparecía no era verdadera, ya que el concejo no había estado nunca en posesión de la libertad que ahora presumía tener, y así no podían ser amparados en la posesión que no tenían. A continuación procedió a desmontar todas las reivindicaciones de los vecinos de la villa. En primer lugat, tanto el señor actual como sus antepasados habían estado en posesión de cobrar por sí y por sus mayordomos todas esas rentas, de entrada eran suyas todas las multas que se imponían a los ganados forasteros por entrar a pastar en el término, es más habia tenido la generosidad de cederle al concejo la mitad de esas penas para que sus guardas pudiesen prender mejor y con más voluntad, y por otra parte nunca se había entrometido en las prendas que la villa tomaba a los vecinos por ese mismo hecho. En cuanto al pan, los vecinos estaban obligados a llevarlo a su costa a Valladolid, pues fue con esa condición con la que habían pactado la entrega del censo anual, y por lo que se refería a la imposición de los $1.000 \mathrm{mrs}$, esta cantidad la recibia de manera justa, como la habían lievado sus antecesores, ya 
que era una obligación contraída por el concejo, en virtud también de ese censo, ya que antes el cabildo nombraba a cuatro personas para que le guardasen el pan, y como el señor se sintió agraviado por las pérdidas que así le venían se avino a que le diesen esos $1.000 \mathrm{mrs}$., y a cambio sus hombres vigilarian ese pan. Además, los vecinos estaban obligados a dar ese pan limpio y cribado, sin mezcla alguna de tierra y paja. Por lo que respecta a las carretadas, siempre se habían dado por esa media de 50 cestos o por carretadas que hacían los 50 cestos. Podría también vedar la caza porque los términos le pertenecían y no al concejo, que nada tenía, salvo lo que el señor y sus antepasados le habían dado, más aún las mismas casas en que moraban eran propiedad del vizconde y pagaban censos por ellas y nadie podía edificar en el pueblo sin su permiso. Es verdad, sin embargo, que el señor les había tomado algunas de sus bestias, pero fueron pocas veces y además les habia pagado por ello, por tanto en este capítulo concreto no había agravio alguno. $Y$ por lo que se refería a la fuente, el argumento que presentaba seguía siendo el mismo, al ser propietario de todo el término de la villa la fuente también le pertenecía, y la podía haber tomado toda para sí pero no lo hizo. Al ser suya la villa, como señor de ella podía traer sus ganados por sus términos sin problema alguno, y a este respecto por la mistma razón tampoco se había excedido ni él ni sus pastores en el cumplimiento de las ordenanzas del concejo por lo que se refería al disfrute de los pastos de las dehesas y prados. Ni siquiera estaba obligado a esperar al día de San Antolín para recibir el pan de la villa, ya que esta tenía la obligación de entregarlo después de cogido. En cuanto a la huerta, el vizconde deseaba que estuviese bien guardada, y sólo les imponía penas suaves a los que entraban en ella sin su permiso. Y en el problema de los jornales les pagaba justamente lo que merecían, así como la imposición de las velas que solo les obligaba cuando había verdadera necesidad para la guarda y defensa de la villa. También debían servir al vizconde dándole huéspedes y ropas, como lo habian hecho siempre a sus antepasados. Finalmente, el procurador de los Vivero manifestó que las canteras y molares eran propiedad del señor como lo era todo el término, y contestó al capítulo del nombramiento de autoridades capitulares afirmando que en esto tampoco había habido agravio ya que, al pertenecer la jurisdicción al señor podía quitar y elegir alcaldes, y si el concejo había usado de ese derecho durante muchos años era porque se lo había permitido el vizconde.

En resumidas cuentas, la demanda desde el punto de vista señorial era nula, y por tanto al emitir sentencia había que absolver al vizconde de los cargos que se le imputaban e imponer perpetuo silencio al concejo de Fuensaldaña. Sin duda alguna la argumentación del procurador de los Vivero resultaba lógica y contundente desde la perspectiva de la naturaleza del régimen señorial, pues en verdad al señor le correspondía el ejercicio de la jurisdicción sobre la villa, y a lo que parecía, según esos puntos de vista, también era, o pretendía ser, el propietario de suelos y términos. De todas maneras implícitamente reconocía algunos agravios, como, por ejemplo, el problema de la fuente o el de los ganados, y, con toda seguridad, tras su hábil respuesta, quedaba muy claro que la mayor parte de estas reivindicaciones eran ciertas, ya que no se negaban de

Hipanaia, LIX/3, núm. 203 (1999) 823-855 
forma sistemática sino que se argumentaba que si se exigian era porque el señor tenía derecho a ello. Por consiguiente era verdad que los Vivero imponían esas prestaciones, pero no había nada malo en ello, no había habido abusos, simplemente se habían limitado a pedir lo que les pertenecía, de acuerdo con la lógica interna del régimen dominical.

El concejo de Fuensaldaña no se dió por vencido y, a través de su procurador, hizo saber su respuesta al señor. Se reafirmaban en sus demandas, negando todos los argumentos esgrimidos por los Vivero. Era falso que les hubiese pagado por exigirles el trabajo de sus animales, los términos eran propios de la villa y por tanto nada podía pedirles al respecto, ni tampoco había carretada en que cupiesen 30 cestos de los que el vizconde decía, carecía de jurisdicción alguna en primera instancia y por tanto no podía nombrar a los oficiales del cabildo, ni eran obligados a darles velas y rondas porque nunca se habían usado ni guardado, por último les había ocupado un prado donde tenía puesto un soto, y otro más junto a la huerta que debería restituirles pues pertenecían a la villa.

La respuesta del vizconde no se hizo esperar. Por lo general reincidia en sus argumentos ya conocidos: la villa y sus términos le pertenecían, por lo tanto sus vasallos estaban obligados a darle todos esos pechos y derechos que les exigía y que siempre, desde tiempo inmemotial, habían dado a sus antepasados, la caza y la fuente eran, por consiguiente, suyas, una mediana carretada de paja había de tener los dichos 50 cestos, podía pedir el pan del concejo desde que eta alzado y nadie podía obligarle a esperar mas tiempo ni había costumbre alguna en contra, y, desde luego, no podía llamarse imposición a la petición de los 1.000 mrs. pues todo ello figuraba en el contrato de censo y así había sido siempre interpretado. Por último, el procurador de los Vivero, afirmaba que no podían exigir la restitución del prado porque no se había presentado en la demanda inicial, era, por tanto, petición nueva, no habia sido hecha por parte bastante, ni en tiempo ni en forma, ni se podía hacer después de la contestación del pleito ni, en fin, el vizconde consentía en ello porque el tal prado era suyo, que lo había heredado de sus antecesores.

Contestación de la villa. Los mismos argumentos ya conocidos. El concejo defendía su libertad, todo lo que pedía era cierto, tenía fundada su intención de derecho común, los vecinos se hallaban exentos de todas las contribuciones que se exponían en la demanda, todos los términos y lo que había en ellos ejidos, pastos, prados, molares, canteras, aguas, fuentes, caza, pesca, multas, aprovechamientos--y la misma jurisdicción les pertenecia y, por consiguiente, jamás habían sido del vizconde, ni, mucho menos, de sus antepasados. Los derechos que pudieran corresponder a los Vivero, continuaba exponiendo el procurador de la villa, los habían traspasado y cedido al concejo a cambio del pago del censo ya mencionado, por tanto no estaban obligados a datle nada más, ni tampoco el vizconde podía sostener que era señor de esos términos, ni siquiera de parte de ellos. De esta manera no podía aprovecharse de ellos, ni vedar cosa alguna, lo que les exigía eran imposiciones y cargas nuevas y por consiguiente eran libres de no satisfacerlas, «pargue son tales que en todo residian el derecho comín» 
y si alguna vez las habían pagado uauia sido por fuerza y temores que les auian echo e puesto el dicho vizconde e sus predecesores por ser señores de la dicha villa, y en tiempo de rebueltas que no auia justizia e que no los podian resistim. Carecian de título y de causa alguna para exigir lo que no les pertenecía, y, además, nunca ni él ni sus antepasados habían puesto impedimento alguno a que los vecinos eligiesen a sus oficiales que juzgasen en primera instancia, porque el señor sólo le correspondía entender en la jurisdicción de la villa en gtado y por vía de apelación. Finalmente, en lo que tocaba a los prados, si que podían añadirlo en la demanda después de la contestación, como cosa aneja y dependiente al contenido principal del pleito.

Los argumentos de las partes estaban ya tan claros que no podía esperarse más que la sentencia. En efecto, el pleito se dió por concluido y las partes fueron recibidas a prueba, que presentaron al presidente y oidores de la Chancilleria de Valladolid. Ambos afirmaron que habían probado bien y cumplidamente su intención y todo aquello que les convenía probar para obtener victoria en el pleito. Una de las partes sostenía que la otra no había demostrado cosa alguna que le aprovechase, ni las pruebas que habían presentado podía perjudicarles porque no fueron hechas ni en parte ni en tiempo, ya que los testigos, además de ser contrarios unos a otros, no daban razones de sus derechos y, por tanto, no deberían haber sido admitidos.

Mientras tanto, muy poco antes de emitirse la sentencia, don Juan de Vivero decidió nombrar un nuevo procurador, nombramiento que recayó en la persona de Alvaro de Betanzos. El nuevo representante de los Vivero procedió de inmediato a hacer una nueva alegación a la Chancillería, en el sentido de que los testigos presentados por el concejo de Fuensaldaña o eran vecinos de la villa $o$ tenían parientes en ella dentro del cuarto grado, por lo tanto les iba su interés en la demanda, eran sospechosos, tenían haciendas en el pueblo y habian vivido en él "por lo cual nunca fé ni prueba hacian, y pidió entero cumplimiento de justician. El alegato fue rechazado y el pleito se dió finalmente por acabado.

La sentencia de vista se pronunció el 31 de enero de 1520. Los magistrados fallaron que el concejo probó bien y cumplidamente su intención, no así el vizconde de Altamira que nada probó al respecto. En cuanto al primer capítulo de la demanda, los jueces estimaron que las multas, tanto las que se imponian a los vecinos como a los forasteros por sus ganados, eran propias de la villa y por tanto el señor no podía cobrarlas. También pertenecian al concejo los molares y canteras que se encontraban en el término del pueblo. Adjudicaban a Fuensaldaña la cuesta del caño porque formaba parte del término. La caza era libre para los vecinos de la villa siempre que guardasen la pragmática y leyes del reino que se referían a esta actividad, y por tanto el vizconde no podía ni prohibirla ni mucho menos imponer multas por ella. El concejo no estaba obligado a dar al vizconde el pan cribado, y las cargas de trigo que tenían que entregarle deberían ser como las demás que se acostumbraban a dar de renta. Tampoco las carretadas tenían necesariamente que medirse por cestos, el vizconde, por consiguiente, no debía apremiarles para que se las diesen por esa medida. El senor no podía exigirles que le entregasen la renta de pan y las carretadas de paja

Hipuna, LIX/3, núm 203 (1999) 823-855 
antes del día de San Antolín. La villa no tenía obligación alguna, ni dentro ni fuera de ella, de recibir huéspedes ni dar ropa al vizconde, ni tampoco a sus criados. Los señores estaban obligados a cumplir y a respetar las ordenanzas de su villa, especialmente los capítulos que se referían al prendimiento del ganado cuando entraba en los prados, dehesas y rastrojos y, en acorralar y encerrar a las reses de noche, aunque naturalmente podían tener en sus términos el mismo número de ganado que los vecinos del pueblo. Los jueces determinaron también que el concejo podía dar al vizconde las bestias que quisiera y que buenamente le pudiese dar, siempre que fuese en aquellos días en que los vecinos no trabajasen en sus labotes, y desde luego pagándole el señor lo que fuese justo por ellas. Condenaron también al vizconde en el capítulo de la fuente, no podría, por tanto, hacer estanque pues la fuente era del pueblo, de tal manera que los vecinos tendrían derecho a aprovecharse de ella cuantas veces lo deseasen. $Y$ en cuanto al nombramiento de los oficiales concejiles, en adelante los vecinos tendrían la facultad de elegir a cuatro hombres buenos de la villa y presentarlos al señor para que, a su vez, éste nombrase a dos de ellos para ejercer el oficio de alcaldes ordinatios en un plazo no superior a cuatro días después de la presentación, ya que de lo contratio perdería este derecho que pasaría de nuevo a los vecinos que así podrían usar de la jurisdicción como si fuesen confirmados por el señor. Lo mismo sucedería con los tegidores: el pueblo seleccionaría a ocho personas y el vizconde elegiría de entre ellos a cuatro siempre que cumpliese con el plazo previsto.

Los jueces de la Chancilleria sentenciaton también a favor del concejo en las restantes peticiones. Así podrían ir a las labores que el señor les solicitase, siempre que no estuviesen trabajando en sus propias labranzas, y siempre, por supuesto, que les pagase por ese servicio su justo y debido salatio. Se le prohibió al vizconde que obligase a los vecinos a darle velas, salvo en caso de necesidad y serían los propios jueces quienes determinasen cuando debería hacerlo. Le ordenaron también que, en un plazo de cuatro meses posteriores a la sentencia, cercase y cerrase su huerta a fin de que no entrase ganado alguno del concejo, y si no lo hacía perdería su derecho a imponer sanciones a aquellos animales que penetrasen en ella. La villa, por su parte, tendría la obligación de llevar el censo del pan a la residencia señorial de Valladolid, y se le daría un plazo de diez días posteriores a la sentencia para que eligiese o bien guardar el pan que debían al vizconde o bien renunciar a ello y pagarle a cambio esos 1.000 mrs. ya mencionados. Por último, los magistrados condenaron también al señor en la cuestión de los prados, que debería restituir a la villa porque pertenecían a sus términos.

La sentencia suponía para los Vivero una derrota completa pues, aunque le reconocían algunos derechos como el de presentación a los cargos municipales por el sistema de personas dobladas, el transporte del pan a su residencia y que pudiesen tener en el término el mismo número de cabezas de ganado que sus vasallos, la realidad era que la justicia les había negado prácticamente todas esas prestaciones y cargas que hasta entonces habian impuesto a los vecinos de la villa por considerarlas innovaciones a todas luces excesivas. A partir de ahora 
no se les toleraría ningún abuso, y mucho menos el intento de resucitar costumbres antiguas abolidas por los tiempos como las sernas encubiertas en trabajo personal y en el de los animales de labor, eso sí sus vasallos podrían trabajar en las tierras señoriales pero siempre a cambio de un salario bien remunerado.

Naturalmente don Juan de Vivero no podía estar satisfecho con el resultado del pleito. La apelación para que la sentencia se revisase no tardó en llegar a la Chancillería. De nuevo se insistía en los argumentos tradicionales, en la costumbre inmemorial que, según el procurador señotial, tenía su parte y sus antepasados de pedir todas esas prestaciones y, sin embargo, nunca el pueblo se había quejado por ello, ni había puesto traba alguna hasta entonces, lo que exigía era simplemente los derechos que a todo señor jurisdiccional le cortespondían en sus dominios propios. Admitía que tal vez los términos podrían ser concejiles, pero sólo en cuanto al derecho de uso, no al de la propiedad, que pertenecía al señor. Por otra parte estaba en su perfecto derecho de multar a los ganados que entraban en su huerta, en primer lugar por el daño que podian hacer y en segundo porque era propiedad personal suya, y el derecho de propiedad era sagrado e inviolable, esta era la ley y lo contrario resultaba injusto. Y en cuanto a las velas, también era injusto que los jueces no hubiesen declarado cuándo había que darlas, más aún cuando afirmaban que habían de darse en tiempo de necesidad, porque así podría suceder que no se defendiese bien la fortaleza recibiendo los vecinos mucho daño por ello, pero es que, además, guardar las velas era una costumbre generalizada en todo el reino de Castilla, y por tanto no había razón ni causa alguna para hacer una excepción con el vizconde. Por último, los Vivero volvían a centrar la defensa de la demanda en el argumento principal: parecía deducirse de la sentencia que el término entero era propiedad del concejo cuando la realidad demostraba lo contrario, la villa de Fuensaldaña carecía de términos públicos, concejiles o baldíos, solo tenía derecho al usufructo porque se los había atrendado el vizconde que era el verdadero propietario, precisamente por ser usufructuarios es por lo que los vecinos habían pactado con el señor la entrega de ese pan y de esa paja, sólo por usar el término labrado, y por esto también pagaban censos por el uso de las casas en las que vivían lo que probaba una vez más que el suelo era propiedad señorial y no del pueblo. El procurador solicitaba, como colofón del discurso, que la sentencia se revocase porque había sido pronunciada sin conocimiento de causa, y exigía a los jueces que declarasen a su parte como señor y propietario de todos los términos del lugar.

Antes de que se presentase la réplica del concejo de Fuensaldaña, el procurador de los Vivero, Alvaro de Betanzos, hizo llegar a la Corona una petición de súplica. en ella recurría a los mismos argumentos, ahora llenos de ligeros matices y de algunas sutilezas. Así al afirmar que todas esas prestaciones las habían llevado desde siempre «pues que por la posesion de tanto tiempo se presumia título e concesion el principab), y sobre todo al recurrir a la monarquía e intentar involucrarla en el pleito, cuando manifestaba que el vizconde y sus antepasados habían conseguido el señorío sobre la villa del propio rey, qué mejor prueba que

Hiaptanti, LIX/3, núm. 203 (1999) 823-855 
aquella ya que los monarcas «tenían fundada su intención en el señorio de todos los lugares que estaban dentro de los limites y mojones destos reynom, y los antepasados del vizconde habían alcanzado "de Nos - es decir la Corona-el título" para que esas tierras le perteneciesen. Este argumento, como sabemos, era manifiestamente falso, ya que los Vivero habían adquirido Fuensaldaña por compra y no por donación real. Suplicaba, por último, al rey que le hiciese justicia, bien anulando por completo la sentencia o bien enmendándola en partes.

El concejo de Fuensaldaña contraatacó por su parte. La sentencia, según su procurador, habia sido «justa y derechamente» dada, no había por tanto lugar a apelaciones, pues ni había sido suplicado por parte ni en tiempo, ni habían sido hechas las otras diligencias que eran necesarias para continuar la dicha súplica, en consecuencia esta última «había quedado y fincado desierta e la sentencia era pasada en cosa juzgaday. Solicitaban su confirmación, a pesar de las razones expuestas por el vizconde, que consideraban que ni eran jurídicas ni verdaderas. De todas maneras el procurador del concejo creyó oportuno entrar a fondo en el contenido de la alegación. Creian en primer lugar, que habia quedado probado de forma muy clara en la sentencia que todos los términos del pueblo eran propiedad del mismo, y por ello podían prender, cazar, etc., y que todo lo demás eran palabras vacías, pues lo que verdaderamente pretendía el vizconde consistía en exigirles imposiciones nuevas que ellos en justicia no podían tolerar. El señor, en todo caso, sólo podía demandarles el censo de pan y las carretadas de paja que se le daban por razón del vasallaje, y no porque tuviese parte alguna en los términos de la villa, porque todo lo demás iba contra el derecho común, las Partidas y el Ordenamiento de Alcalá. Además, si se le condenaba en todas esas exigencias, no perdía por ello el señorío sobre la villa que lo seguiría conservando a pesar de todo. $Y$ en cuanto al resto, la verdad es que carecía de título alguno para imponer la entrega de gallinas por el uso de los suelos sobre los que se levantaban las casas, si tenía la huerta abierta se exponía por ello a que le robasen, y finalmente no había razón alguna para dar velas porque el concejo sabía lo que debía hacer para defenderse en caso de necesidad.

Los argumentos que utilizaban ambas partes se repetían casi constantemente, pocas novedades se introducían, salvo matices a las alegaciones principales y a veces alguna idea un poco más original. A este respecto, el procurador de la villa supo encontrar una hábil respuesta al razonamiento principal de los Vivero, cuando rechazó de plano lo de tiempo inmemorial por falso y porque no podía probarse, ya que la villa era señorío de este linaje desde mediados del siglo XV en que la compró el bisabuelo del vizconde, el Contador Alonso Pérez de Vivero, es decir no hacía ni siquiera un siglo, y, por consiguiente, ni este último ni sus sucesores habían presentado privilegio ni testimonio alguno de que cobrasen desde siempre esos derechos. Con este argumento el procurador liquidaba de hecho la pretensión fundamental de los señores, y sin duda cualquier derecho que tuviesen, si es que alguno tenían, a exigir todas esas prestaciones que habían originado el conflicto. Había además confusión, común por otra parte en la época, entre la propiedad eminente y el derecho de uso a esa 
propiedad. Algo de razón, sin embargo, llevaban los Vivero cuando exigían la propiedad sobre los suelos de las casas, ya que, como sabemos, habian sido comprados con la villa, pues de otra manera, no se explica el que tomasen posesión de ellos en 1422. Al final los jueces les reconocerían este último derecho.

Se le dió traslado de la respuesta concejil a la parte contraria, que respondió con los mismos argumentos que ya conocemos. Hubo una novedad que no figuraba entre las peticiones anteriores: el procurador del vizconde negaba que éste hubiese construido un molino y un horno en suelo ajeno, antes bien lo había hecho en suelo propio, y por tanto los vecinos de la villa no tenían derecho alguno para exigir que los derrocasen.

Pleito concluido, las partes fueron recibidas a prueba, pero ninguna de ellas presentó nada. El 6 de octubre de 1525 llegó la sentencia en grado de revista. confirmación de la anterior con una declaración: los magistrados de Valladolid condenaban al vizconde a que desde ahora y para siempre no exigiese a sus vasallos de Fuensaldaña las 230 gallinas que había llevado hasta aquí, además de las del censo, por razón de los suelos de las casas de los vecinos. No hubo condena de costas, pero a través de esta última nota sabemos ahora que en la villa residían 230 vecinos pecheros.

Súplica contra la sentencia por parte de Andrés de Ribera, nuevo procurador del vizconde. Confirmación de la misma en 1526. Los Vivero habían perdido. No obstante, aún quedaba un epílogo: todavía podían hacerse con el censo de las 230 gallinas que los vecinos pagaban por razón de los suelos. Los señores no dudaron, había que agartarse a un clavo ardiendo, aunque éste fuese una cosa bien insignificante como la demanda de unas aves. No estaban dispuestos a perderlas, aunque fuese solamente por el prurito del honor. Y así volvieron a la carga con el argumento de que no había ninguna justicia que pudiese condenarles en la exigencia de esas gallinas, ya que los antepasados del vizconde habían dado suelos para edificar sus casas con la contrapartida de entregarles por cada uno las gallinas que merecía de renta, según la calidad y lugar del suelo. Es más había vecinos de Valladolid que tenían casa en Fuensaldaña y también contribuían por ellas con esas aves. Eran los vecinos quienes las entregaban, de manera que la demanda no debería haber sido presentada por el concejo, sino por los particulares que poseian esas casas. Solicitaban, por tanto, la supresión de ese punto concreto. Por otra parte, en todo el proceso no se había presentado petición alguna por parte del concejo acerca de un soto de madera y árboles que estaba cerca de la huerta, no había habido artículo ni pregunta sobre ello, y, sin embargo, el concejo, al recibir la sentencia, amenazó con que había de talar ese soto. Esta amenaza, de llevarse a cabo, provocaría un gran daño al vizconde, y aún al propio concejo, por consiguiente suplicaban a los jueces que no ordenasen que la cuestión de ese soto estuviese en la sentencia anterior y pudiese así recuperarlo el señor.

Se le dió traslado al concejo de la nueva petición del vizconde. La respuesta fue contundente: no había necesidad de súplica porque se trataba de una sentencia de revista, y además, lo que se demandaba había sido ya juzgado previamente en primera y segunda instancia, y por lo tanto no había grado para

IIípunia, L.IX/3, núm. 203 (1999) 823-855 
conocer más de ello, ni la parte perdedora podía ya apelar la sentencia de tevista. Por otra parte, el soto se incluía en los términos de la villa que, como la sentencia manifestaba, pertenecían al concejo, no habia por tanto necesidad alguna de talarlo porque era suyo. Exigieron, en consecuencia, la confirmación de la sentencia anterior.

El procurador del vizconde se aferró, de forma un tanto patética, a su discurso anterior: el tema de los suelos nunca había sido exigido por Fuensaldaña, ni se había hecho mención de ello en la primera sentencia, solo aparecía en la de revista, por lo tanto había necesidad de una primera sentencia. El concejo, por su parte, le respondió que precisamente era lo contrario de lo que afirmaba.

Así quedó todo. El pleito había finalizado ${ }^{28}$. Los magistrados pronunciaron un auto y mandamiento por el que recibieron a prueba a la parte del vizconde, y dieron traslado de la querella al concejo de Fuensaldaña. El 21 de julio de 1528 se dió sentencia definitiva en gtado de revista. Esta vez la demanda señorial obtuvo éxito: el obispo de Badajoz, como presidente de la Chancillería, dió la razón al vizconde en la exigencia de las gallinas, pero sólo podía pedirlas por los suelos que habían sido cedidos hasta el mismo día de la sentencia ya que desde ahora el derecho de propiedad se reservaba al concejo y no al señor ${ }^{20}$.

El resultado del conflicto está a la vista. El concejo, tras una dura, costosa y lenta batalla legal, había triunfado. Los Vivero habian sido derrotados en toda regla, sólo ya al final, en una angustiosa pelea, consiguieron, al menos, conservar las gallinas que, por otra parte, era justo que se las concediesen ya que, como hemos visto líneas atrás, en la compra del pueblo entraban los suelos y, por tanto, estaban en su perfecto derecho de exigir esa prestación. Peto en todo lo demás perdieron. Final feliz para el pueblo de Fuensaldaña.

\section{CONCLUSIONES}

A mediados del siglo $\mathrm{XV}$, y tras pasar por diversas vicisitudes, la villa de Fuensaldaña pasó a formar parte de los señoríos de un linaje, los Vivero, que había tenido su origen en la persona de un letrado que, merced a la protección de Alvaro de Luna, había logrado hacerse con el oficio de Contador Mayor de la hacienda regia, un alto puesto de la administración central del reino de Castilla. Este petsonaje, Alfonso Pérez de Vivero, supo aprovechat bien su cargo, así como la posición social y los beneficios económicos que de él se derivaban, para conseguir un patrimonio propio, unas bases materiales que le permitieran convertirse en noble. El conjunto de sus posesiones, tal como nos la muestra el mayorazgo de 1452, da la impresión de que no fueron adquiridas siguiendo un plan previamente organizado, pues su grado de dispersión era bastante notable, aunque desde luego fue en el término de Valladolid donde este hombre

28 El pleito en $A . C . D . A ., \mathrm{N}^{\circ} 186$, Leg. $5, \mathrm{n}^{\circ} 6$.

29. La carta de Carlos V con la ejecutoria de la sentencia está fechada en Valladolid el 30 de septiembre de 1528.

Hispania, LIX/3, núm. 203 (1999) 823-855 
concentró el núcleo principal de ellas. No era nada de extraño por otra parte, pues en esa villa se hallaba la Corte y en ella, por las necesidades de su oficio y desde luego por la cercanía al poder, tenía forzosamente que fijar su residencia. Todo ello nos lleva a la conclusión de que es muy probable que utilizase todos los medios puestos a su alcance para acaparar posesiones donde fuese, aprovechando las oportunidades que le concedía su proximidad al poder y el ejercicio de su cargo. Lo que hizo posible que su patrimonio se formase a través de donaciones regias y de compraventas, pero también de confiscaciones de propiedades que Vivero supo, con fortuna, hacer suyas.

El patrimonio creado por el Contador Mayor pasó íntegro a sus sucesores, que supieron mantenerlo y disfrutarlo durante varias generaciones, con tan solo una pérdida, Viveiro, la villa más importante de todas sus posesiones, que se vieron obligados a ceder a los Reyes Católicos, a cambio de unas rentas fijas. La pérdida de la villa lucense puso en primer plano de actualidad a Fuensalda$\tilde{n}$ a, que desde entonces pasa a ser la principal de sus dominios. Pronto, la necesidad de disponer de más rentas obligó a los Vivero a iniciar un peligroso camino de presión fiscal sobre ese pueblo, a todas luces abusiva, que a la larga les levó a un enfrentamiento directo con sus vasallos. Estos últimos acudieton en principio a la vía el pacto con sus señores, pero sin resultado alguno. Los Viveto, obcecados en sus exigencias, que los vecinos no podían soportar, creyeron que su alta posición social constituía un seguro formidable para aguantar todo tipo de embestidas, y desde luego para continuar imponiendo sus exacciones. En su ceguera no tuvieron en cuenta la valentín y el arrojo que demostraron poseer sus vasallos, que hicieron frente a las arbitrariedades con los medios legales que únicamente tenían a su alcance. Así se inició un largo conflicto que desembocó en una completa derrota de los señores. La justicia, finalmente, se impuso. Los Vivero perdieron todo lo que hasta entonces habian impuesto por la fuerza. Quizá si hubieran aceptado la vía del acuerdo, es posible que hubiesen mantenido algunas de esas imposiciones, pero su soberbia de grandes señores les perdió. El hecho cierto es que, en este caso concreto, y al contrario de otros similares que tuvieron lugar en la misma época, que sólo lograron sentencias salomónicas que intentaban contentar a ambas partes, el pueblo de Fuensaldaña obtuvo en su larga lucha satisfacción completa a sus reivindicaciones.

Una última reflexión se impone, al hilo de lo que acabo de afirmar en el párrafo anterior. Si observamos con cierto detenimiento la naturaleza de las imposiciones señoriales que se declaran en la demanda, nos damos cuenta de inmediato que la mayor parte de ellas son muy semejantes a las de otros concejos de señorío que, por la misma época, plantean también pleitos contra con sus señores. Así, por ejemplo, el capítulo que se refiere al nombramiento de los oficiales concejiles se repite casi constantemente en las quejas de otras villas de señotío como Fuensalida, Ezcaray y Paredes de Nava ${ }^{30}$. A fines del siglo XV

30 Montero Tejadn, Rosa María, art.cit., págs. 346 y 347; Franco Sil.va, Alfonso, E/ Condado de Fuensalida en la Baja Edad Media, Cádiz 1994, págs. 117-118.

Hikpania, LIX/3, núrm. 203 (1999) 823-855 
los señores trataron de limitar la autonomía concejil, intentando controlarla en su propio beneficio mediante la designación de personas fieles. Los vecinos muy celosos de esta prerrogativa, se oponían a ese abuso, y para ello recurrieton con frecuencia a los tribunales superiores de la justicia real con la esperanza de obtener éxito en su demanda. Las Chancillerias, en casi todos los casos, optaton por imponerles el modelo de personas dobladas para cada cargo, es decir intentaban satisfacer a amabas partes, a los vecinos con el derecho de presentación y a los señores con la facultad de poder elegir a uno o a varios de los nombres que figuraban en la lista que el concejo saliente le entregaba. Aún así, en algunos casos concretos no contentaron a nadie, y los pleitos, por tanto, se eternizaban quizás, como ha puesto de relieve Monsalvo Antón, por la gran variedad y complejidad que habia en las villas señoriales a la hora de designar y nombrar a los oficiales públicos ${ }^{31}$. También es posible que en este aspecto concreto de las relaciones señor-vasallos influyera el momento, el modo y la forma de la entrada del pueblo en régimen señorial. Hay que pensat que la señorialización avanzó de forma extraordinaria desde la época de Entique II, y sobre todo durante el siglo XV. Muchas de las villas que fueron entregadas por la monarquía a señores particulares en esa época tenían ya una larguísima etapa, de varios siglos incluso, de autonomía concejil muy bien organizada. La llegada de un señor siempre podía significar la introducción de novedades a este respecto. No era raro, por tanto, que las oligarquías que ditigían esos concejos pudiesen ver amenazados ahora sus intereses y tratasen de evitarlo en la medida de sus posibilidades. Si el señor se veía obligado a pactar con el grupo dirigente no había problemas, pero si no lo hacía, o si violaba alguna de las reglas del pacto, tarde o temprano estallaría el conflicto, bien, a través de una revuelta abierta, $o$, lo que fue más frecuente, mediante la vía judicial o resistencia pasiva como la define J. Valdeón ${ }^{32}$. Parece que es a esta última a la que se recurre con gran facilidad desde el reinado de los Reyes Católicos en adelante.

Otro tanto ocurría con la obligación de dar huéspedes y ropas, quizá un recuerdo del viejo yantar. Se exigia en Fuensaldaña y en otras villas como Galisteo, Paredes de Nava, Lerma y algunas otras ${ }^{33}$. Esta arbitraria costumbre solía traer gastos de consideración para los concejos, por eso siempre se oponían a ella. Y lo mismo sucede con la prestación gratuita de transportes, la obligación de trabajar para los señores a modo de recordatorio de las antiguas sernas, la usurpación de tierras del término concejil, la percepción de multas muy elevadas por la entrada del ganado local en esos términos y la veda de la caza para

31 MONSA signación de corregidores, alcaldes y alguaciles en un concejo del siglo XV", Studia Historica, V (1987), págs. 173-174.

32 Op.cit., pág. 23. Algunos otros ejemplos de resistencia pasiva en MONTERo TEJADA, Rosa María, art.cit., págs. 359-366, y Franco SILVA, Alfonso, (dLa Fortuna y el Poded, págs. 231-238 y 254-261.

33 Montero Tejada, Rosa María, art. cit., págs. 345-346; para Lerma, Franco Silva, Alfonso, Señores y Señorios, Jaén, Publicaciones de la Universidad, 1997, págs. 105-106. 
uso y disfrute exclusivo del señor, etc. ${ }^{34}$. Todos estos abusos se repiten muy a menudo en los pliegos de quejas que los vasallos de señorio se atreven a elevar a la Chancillería, indicio evidente de que en la mayor parte de los casos se trataban de tributos nuevos que los nobles solian imponerles para incrementar sus rentas, o bien eran obligaciones que se exigían desde mucho tiempo atrás, y sólo es ahora, desde fines del siglo XV, cuando los sufridos vecinos de esas villas se habian decidido finalmente a denunciar. El hecho cierto es que la extorsión, los abusos, la violencia incluso, se daban con tanta frecuencia en las villas sometidas al régimen señorial, sobre todo en aquellas que, a partir de la época Trástamara habían sido enajenadas del realengo y entregadas por la $\mathrm{Co}-$ rona a sujetos particulares que hasta entonces no habían tenido vinculación alguna con ellas ${ }^{35}$. En cualquier caso esos pueblos nunca denunciaron la existencia misma del régimen señorial, tan solo sus abusos, quizá no eran conscientes de que tales extorsiones se hallaban implícitas en la propia naturaleza de ese modelo de organización social, o mejor, quizás es que nada podían hacer en aquella época para derribarlo.

\section{APÉNDICE DOCUMENTAL}

$\mathbf{1}$

1435, septiembre, 6. Santa Maria.

Diego Sarmiento, Adelantado Mayor del reino de Galicia, dona a Alfonso Përez de Vivero, los bienes, casas y heredades que posee en Fuensaldaña. A.C.D.A. N⿳2 185, Leg. 2, $\mathrm{n}^{\mathrm{2}} 1$. Copia simple del siglo XVIII.

Sepan quantos esta carta vieren como yo Diego Sarmiento, Adelantado Mayor de Gallicia e del Conseio de nuestro señor el rey, de mi libre e propia voluntad sin premia nin induzimiento alguno, otorgo e conosco por esta presente carta que fago donación e do en puro donadio buena e pura e perfecta e non revocable ligítima e estable, que es dicha entre vivos, para siempre jamás a vos Alfón Pérez de Vivero, contador mayor del dicho señor rey, e para vos e para vuestros herederos e sucesores, e para vender e empeñar e dar e donar e trocar e cambiar e enagenar e traspasar e facer como de vuestra cosa propia, e para aquel o aquellas que de vos e de los dichos vuestros herederos e sucesores ovieren causa, o de aquel o aquellos que de vos o dellos o de qualquier de vos e delos lo ovieren, e lo vos a ellos dierdes e tomardes e cambiardes o enagenardes

34 MON'ERo TEjada, Rosa María, art.cit., págs. 351-354.

35 Una magnífica relfexión sobre los concejos de señorio, llena de ideas nuevas, que abre numetosas e importantes vias de investigación es el trabajo de Monsalvo Anión, José Maria, "Historia de los poderes medievales: del derecho a la Antropología (el ejemplo castellano)", en Carlos Barros, editor, Historia a Debate. Medieval, págs. 81-149, Santiago de Compostela, 1995.

Hihpania, LIX/3, núm. 203 (1999) 823-855 
o traspasardes o promutardes en qualquier manera, de todos los vasallos que yo he e tengo e me pertenesen aver e heredar en qualquier manera, así por herencia como por compra o dádiva o en otra qualquier manera, e por qualquier razón e causa que sea e ser pueda en Fuente Saldaña, que es cerca de la villa de Valladolid, con la justicia cevil e criminal e mero misto imperio alto e baxo e con todos los derechos e rentas e títulos e servicios e pan e vino e dineros e aves e jornales e obrerizos e otros qualesquier servicios que a mi son tenudos e obligados e están en uso e costumbre de dar e dan. E otrosí más de todas las heredades de pan levar aboyadas e por aboyar e casas e solares e corrales e huertas e viñas e prados e pastos e montes e dehesas e ejidos e eras e fronteras, e otras qualesquier heredades que a mi pertenecen e poseo e devo aver en el dicho lugar de Fuent Saldaña e en su término, esto en remuneración e por muchos catgos que de vos tengo, e que yo e mi padre García Ferrandes Sarmiento que Dios aya e mi abuelo tenía de vuestro padre e de otros de vuestro linaje, los quales cargos montan e valen mucho más que esta donación que vos yo fago, de que conosco que vos soy en mucho más tenudo e encargado a satisfacer.

E fago vos la dicha donación con la dicha justicia cevil e criminal e mero mixto imperio, como dicho es, desde oy dia en adelante que esta carta es fecha para siempre jamás con todas sus entradas e con todas sus salidas e con todas sus pertenencias e con todos sus derechos e usos e costumbres útiles e directas quantos han e aver deven así de fecho como de derecho en qualquier manera. E por esta presente carta desde oy dicho día en adelante que esta carta es fecha me desapodero e derelinco de todo lo sobredicho e de cada una cosa e parte dello, e quito e parto a mi e a mis herederos e sucesores de todo ello e de todo quanto poder e derecho e tenencia e posesión e propiedad e señorío e vos e razón e abción cevil e natural, que yo he e aver puedo en qualquier manera e sobre qualquier razón a todo lo sobredicho, e a qualquier cosa e parte dello, e lo do todo e traspaso e apodero e entrego en todo ello a vos el dicho Alfón Peres de Vivero, para que sea todo vuestro libre e quito de aquí adelante para siempre jamás e para vuestros herederos e sucesores e para los que de vos venieren e descendieren libre e desembargadamente por juro de heredad para siempre jamás. E por esta carta vos do poder cumplido e licencia según que de derecho en tal caso se requiere, para que por vos mesmo lo podades entrar e tomar la tenencia e posesión e propiedad e dominio de todo lo sobredicho e de cada cosa dello sin mi licencia e sin licencia nin abtoridad de ningund alcalde nin de juez, que sea eclesiástico o seglar, e sin pena alguna, e lo vender e empeñar e dar e donar e trocar e cambiar e enagenar e promutar, como dicho es, e facer de todo lo sobredicho e de cada cosa dello así como de vuestra cosa mesma propia quita e esenta sin embargo nin contradición alguna de mi nin de otro por mi nin de otra persona alguna, más todavía retifico e he por rata e grata e firme e estable e valedera agora e para en todo tiempo e siempre jamás esta dicha carta de donación e cada cosa dello e vala e sea firme. E prometo vos por mi e por mis herederos e sucesores e por cada uno dellos de la guardar e mantener e cumplir e de non ir nin venir yo nin ellos ni otro por mi ni por ellos contra esta dicha carta ni contra parte della por la remover e retratar por ninguna ni alguna razón 
ni causa que sea o ser pueda ante ningund jues ni alcalde, que sea eclesiástico ni seglar, ni puesto por caso que cayesedes a mi o a mis herederos en algund caso de los que fuero e derecho pone, porque pueden revocar qualquier donación aquel que la faze a otra persona después de su muerte o en su vida, e yo seyendo cierto e certificado de las dichas leyes e de cada una dellas renunciadas espresamente, e renuncio que non puedades ir nin alegar que non fui dello certificado en la manera que dicha es. E si yo o otro por mi contra esta carta ficere o veniere por la contradecir o impunar en cosa alguna por alguna razón e tiempo alguno que sea en juicio o fuera de juicio, que vos peche e pague en pena $\mathrm{e}$ por postura e por convención asosegada que conmusco pongo dos mill florines de buen oro e de justo peso del cuño de Aragón por cada día e por cada vez que contra ello fuere o veniere en pena e por pena e en nombre de intereses, e la pena pagada o non pagada todavía que esta carta sea firme e estable e valedera para siempre jamás, e que yo o quien mis bienes oviere seamos tenudos e obligados a vos redrar e amparar e defender e fazer sano todo lo sobredicho e cada cosa dello de cualesquier persona o personas que vos lo demanden o embarguen o contraríen todo o parte dello, desde'l día que por vos o por otra persona en vuestro nombre sobrello fuere requerido yo o mis herederos en dies días, so la dicha pena, e más que vos peche e pague todas quantas costas e daño e menoscabos por la dicha razón a vos o a otros por vos se vos recrecieren en estable, como dicho es. E para mejor tener e guardar e cumplir todo lo sobredicho e cada cosa dello e para pagar las dichas penas e cada una dellas, si en ellas cayere, obligo a ello a mi mesmo e a todos mis bienes, así muebles como raices avidos e por aver, por do quier que los yo aya, e do poder en mi e en ellos por esta carta a qualesquier alcaldes e jueces e justicias, así de la corte e chancillería del dicho señor rey como de otras qualesquier cibdades e villas e lugares de los sus regnos e señorios de qualquier condición o estado o preheminencia que sean ante quien esta carta fuere mostrada e pedido cumplimiento della que me puedan compeler e compellan e aptemien e costringan por todos los remedios del derecho a que siempre tenga e cumpla $\mathrm{e}$ pague e guarde e aprueve esta carta e todo lo en ella contenido e cada cosa deIlo con las claúsulas e firmezas e posturas en ella contenidas, e que me tomen de los dichos mis bienes los que bastaren e los vendan segund fuero, e de los maravedís que valieren que entreguen e fagan pago a vos el dicho Alfón Peres de Vivero, o a quien por vos lo oviere de aver e de recabdar a tan bien de todo el debdo principal como de las dichas penas e costas e daños e menoscabos de todo bien e cumplidamente en guisa que vos non mengue ende cosa alguna, bien así a tan cumplidamente como en contra mia fuese dado sobrello sentencia difinitiva por jues competente e pasada en cosa judgada e por mi procurada e amologada e consentida entre partes. E qualquier que mis bienes comprare que por esta razón me fueren vendidos yo me obligo de gelos facer sanos agora e para siempre jamás, bien así como si yo mesmo gelos vendiese de mi propia voluntad, e sobre todo esto que dicho es renuncio e parto de mi todo tiempo feriado qualquier que sea de pan e vino coger e todas cartas e todos privilleios e franquezas e metcedes e libertades de tey o de reyna o de ynfante o de rico

Hippania, LIX/3, núm. 203 (1999) 823-855 
ome o de otro señor o perlado qualquier que sea renuncio que non pueda decir nin alegar nin poner en juicio nin fuera del por mi nin por otra persona en mi nombre contra esta carta acusación nin acusaciones nin reclamaré contra ello nin contra parte dello en que fue nin es simulado selición de dolo alguno nin dilatoria nin perentoria que contra esta carta pueda set opuesta por alguna causa o razón que sea o ser pueda, ca todo lo renuncio e parto de mi espresamente e quiero que me non vala en juicio nin fuera del. Otrosí renuncio e parto de mi todas las razones e defensiones e exebciones declinatorias perjudiciales presentes futuras que contra esta carta e contra lo en ella contenido podiese en algund tiempo alegar e poner por manera de abción o demanda o denunciación o por reconvención o por imploración de beneficio de jues, ca puesto caso quel dicho jues sin gelo yo pedir de su oficio e propio motu lo pueda rebtar o desfacer o comular en todo o en parte, todo quiero e renuncio que me non vala nin me pueda dello acoger nin usar nin aprovechar. E renuncio e quito e parto de mi toda ley e todo fuero e derecho canónico e cevil escripto o non escripto, ordenado o por ordenar, e todo decreto e auxilio o ingratitud de derecho, e el traslado desta carta e de parte della, e la demanda en escripto o por palabra. E otrosí renuncio todo beneficio de restitución in integrum por orden de caballería, e otorgo e quiero ser judgado por aquelia ley del derecho e ordenamiento que dice e comienza pareciendo que alguno se quiso obligat a otto sea tenudo de lo complir. E otrosí quiero ser judgado por aquella ley que dice que todos los pleitos e posturas e contrabtos e convenencias que fueren fechos entre los omes por escripto, en que fuere puesto el día e el mes e el año e el lugar en que fueren fechas que deven ser para siempre firmes e valederas. E otrosí renuncio la lay del derecho en que dice que general renunciación non vala. E otrosí renuncio la ley que dice que donación que ome faga de todo lo suyo que non vala, e la ley que dice que ninguno no puede facer donación más de en quinientos sueldos, por ende quanto más vale esta dicha donación de los dichos quinientos sueldos tantas donaciones vos fago bien así e a tan cumplidamente como si fuesen fechas muchas donaciones e en tiempos de partidos otorgadas. E por más satisfacer do vos esta carta en señal de dada tenencia e posesión e propiedad e señorío de todo lo sobredicho corporalmente vel casi, e porque esto sea cierto e fime e non venga en dubda otorgamos esta carta ante Juan Rodrigues el mozo, escribano de nuestro señor el rey e su notatio público en la su corte e en todos los sus reynos e señoríos e escribano público por nuestra señora la reyna de Castilla en la villa de Santa María la Real cerca de Nieva, el qual tuego e mando que faga o mande faser esta carta a vista de letrados e la signa de su signo, e a los presentes ruego que sean de los testigos.

Fecha en la dicha villa de Santa María seis días del mes de septiembre año del nascimiento del nuestro señor Jesucristo de mill e quatrocientos e treinta $e$ cinco años. Testigos que estaban presentes llamados Lope de Orzales, e Pedro de Baez, e Juan de Medina, escribano, escuderos del dicho Adelantado e otros etc. E yo Juan Rodrigues el mozo escribano e notario público sobredicho fui presente a todo esto que dicho es con los dichos testigos, e por ruego e otorgamiento del dicho señor Adelantado fise escribir esta carta en estas dos fojas

Hispania, J.IX/3, núm. 203 (1999) 823-855 
de pergamino, e por ende fise aquí este mio signo en testimonio de verdat. Juan Rodrigues.

1436, marzo, 8. Monreal.

Martín de Luna vende a Alfonso Pérez de Vivero todos los bienes que posee en Fuensaldaña.

A.C.D.A. $\mathrm{N}^{2} 185$, Leg. $2, \mathrm{n}^{\mathfrak{2}}$ 1. Copia simple del siglo XVII.

Sepan quantos esta carta vieren como yo Martín de Luna, guarda de nuestro señor el rey e hermano del señor don Alvaro de Luna condestable de Castilla e conde de Santistevan, conosco e otorgo que vendo a vos Alfón Péres de Vivero, contador mayor del dicho señor rey, que estades absente bien así como si fuesedes presentes, para vos e para vuestros herederos e sucesores e para aquel o aquellos que de vos o dellos ovieren causa todas las tierras e heredades e bienes e solares e otras cosas que yo he e me pertenecen aver en Fuent Saldaña, cerca de Valladolid, con todos los vasallos e con todas las rentas e derechos e pertenencias que yo he e me pertenecen, e con toda la jurisdición e justicia cevil e criminal alta e baxa e mero mixto imperio, e con todas las rentas e frutos e derechos e pechos ordinarios e extraordinarios, e con todas las heredades casas e solares e viñas e tietras de pan levar e eras e prados e pastos e huertas e montes e aguas estantes e corrientes e manantes, e con sus términos e con todos los bienes e aparejos de labranza e otras cosas que yo hé tengo e me pertenece en el dicho lugar Fuent Saldaña e en sus términos, en qualquier maneta e por qualquier cabsa, título e razón que sea o ser pueda, lo qual todo e cada cosa e parte dello vos vendo vendida buena e sana e salva sin entredicho e sin cotradición alguna con todo el señorío e títulos e posesión e fuero e derecho e uso e costumbres e con todas sus entradas e salidas e pertenencias e usos e derechos, quantos ha e aver deve de fecho e de derecho en qualquier manera e por qualquiet causa e razón que sea, así como señor dello e como poseedor junta e apartadamente por precio e quantía de setenta mill maravedís desta moneda usual, los quales me dió en vuestro nombre e por vos Arias de Tinco o Men de Fernando de Vivero, criado del dicho señor rey, e yo del recebí, e pasaron a mi poder contados realmente e con efecto en buenas doblas de oro, en que los montó antel notario público e testigos presentes que vieron facer la paga. Sobre lo qual renuncio toda ley e todo fuero e derecho e desde oy día que esta carta es fecha en adelante me desapodero de todo el poder e derecho de la propiedat e señorío e posesión cevil e natural e corporal e casi posesión, que yo he e me pertenece a mi e a mis herederos por siempre jamás de todos los dichos vasallos con todos los pechos e derechos e rentas e fueros e serventias, que me son tenudos a dar e me pertenece aver, e de toda la dicha jurisdición $\mathrm{e}$ justicia cevil e criminal alta e baxa e mero mixto imperio que yo he e tengo e

Hispania, LIX/3, núm. 203 (1999) 823-855 
me pertenece e pertenecer debe en todo ello. E otrosí de todas las heredades casas e solares viñas huertas prados pastos montes aguas e fuentes e otras qualesquier cosas que yo he e tengo en el dicho lugat Fuent Saldaña, e me pertenecen e pertenecer deben como señor dellos junta o apartadamente en qualquier manera e por qualquier causa e razón que sea, por tal manera que en mi nin mis herederos e sucesores non quede posesión nin casi posesión nin propiedat nin señorío en todo lo sobredicho nin en cada cosa nin parte dello. E apodero en todo ello a vos el dicho Alfón Peres para vos e para vuestros herederos e sucesores e para aquel o aquellos que de vos o dellos ovieren causa, e vos fago exseción e traspasamiento de todo ello e cada cosa e parte dello e de todos los derechos e aciones útiles e diretas que yo e mis herederos e sucesores avtían e podrían aver en todo ello e en cada cosa e parte dello libre e desembargadamente, para que lo podades vender e empeñat e donat e cambiar e facer de todo lo sobredicho e de cada cosa e parte dello todo lo que quisieredes e por bien tovieredes como de cosa vuestra propia libre e quita e desembargada avida de justo título con buena fee para agora e para siempre jamás.

E por esta carta vos do e otorgo poder cumplido e libre e llenero a vos el dicho Alfón Peres o a quien vuestro poder oviere, para que sin mi e sin mi mandado e sin licencia nin abtoridat de alcalde ni de juez ni de otra persona, e sin pena e calupnia alguna podades entrar e tomar e entredes e tomedes la tenencia e posesión cevil e natural de todas las dichas heredades, casas e solares, viñas e huertas, prados, pastos e montes e aguas corrientes e estantes e manantes, e de toda la dicha jurisdicción e justicia cevil e criminal e vasallos e rentas e pechos e derechos ordinarios e extraordinarios, e de todo lo sobredicho e de cada cosa e parte dello para vos e para vuestros herederos e sucesores, e para aquel o aquellos que de vos o dellos ovieren causa non embargante qualquier resistencia actual o verbal constituyéndome como constituyo por la presente por poseedor en vuestro nombre de todo lo sobredicho e cada cosa e parte dello fasta que vos o quien vuestro poder oviere corporal e actualmente aprehendades e tomedes la dicha posesión cevil e natural o corporal e casi posesión de todo lo susodicho e cada cosa e parte dello. E otorgo por mi e por mis bienes avidos e por aver, raices e muebles, ganados e por ganat, e por mis herederos e sucesores, e por aquel o aquellos que de mi o dellos ovieren causa, de vos facer sanos los dichos vasallos e jurisdición e justicia cevil e criminal alta e baxa e mero misto imperio e heredades e casas e viñas e huertas e montes e prados e pastos e fuentes e pechos e derechos e rentas con todo lo sobredicho e cada cosa e parte dello que vos así vendo e de vos redrar e defender e amparar e sacar a paz e a salvo a vos el dicho Alfón Péres e a vuestros herederos e sucesores, e aquel o aquellos que de vos o dellos ovieren causa, con todo lo sobredicho e cada cosa e parte dello en qualquier manera e tiempo e lugar e jurisdición e por qualquier causa e razón que sea. E otorgo de aver siempre por firme esta dicha vendida e otorgamiento yo e los dichos mis herederos e sucesores, e de non ir nin venir contra ella ni contra cosa alguna nin parte della, aunque diga o alleguen que en esta dicha vendida oviese recebida daño e engaño, nin que los dichos vasallos e rentas e pechos e derechos que yo he e me perte- 
nece aver en el dicho lugar Fuent Saldaña con la dicha jurisdición e justicia cevil e criminal alta e baxa e mero e mixto imperio, e con todas las dichas heredades tierras e casas e viñas e huertas e solares e prados e pastos e montes e con todo lo sobredicho que yo he e tengo e me pertenece e pertenecer deve en el dicho lugar que vos así vendo vos los oviese vendido por mas de la meytad de los dichos setenta mill maravedís del dicho precio, que por compra dello el dicho Arias me dió e pagó por vos e en vuestro nombre, porque la verdat es que non vale nin puede valer más, e así lo falle e fuy e so certificado dello que'l justo precio e valor de todo lo sobredicho es los dichos setenta mill maravedies, que por compra de todo ello el dicho Arias por vos e en vuestro nombre me dió e pagó, como dicho es, e si más vale o puede valer poco o mucho más quel dicho precio quanto quier que más valiese e puede valer por la presente lo do e traspaso e fago de todo ello e de cada cosa e parte dello a vos el dicho Alfón Péres para vos e para vuestros herederos e sucesores e para aquel o aquellos que de vos o dellos ovieren causa para siempre jamás cesión e traspasamiento e donación buena e pura e sana perfecta inrrebocabile, fecha entrevivos, dada e entregada luego de mano sin embargo e sin condición e sin contradición alguna por muchas buenas obras que de vos he recibido e cargo que de vos tengo tantas e de tanto valor e misterio que montan e valen tanto e más que los dichos vasallos e jurisdición e justicia e pechos e derechos e rentas heredades tierras e casas e viñas e montes e pastos e cosas sobredichas que así vos vendo, e otorgo de los non revocar esta dicha donación que vos fago por bien decir que desfalleciese en la insinuación e decreto de juez, e fuese de mayor quantía o valor que la ley otorga, nin porque diga o allegue que me oviesedes sido en desagradecimiento o que interveniese alguno de los casos que los derechos ponen, poque las donaciones se puedan revocar o desatar. E otrosí otorgo e conosco por mi e por mis bienes e herederos e sucesores que vos faré e fago sanos e libres e sin letigio e quitos e desembargados de toda servidumbre e tributo e fuero sin impedimento e sin embargo e sin turbación e sin contradición alguna de fecho e de derecho los dichos vasallos con todos los dichos pechos e derechos e rentas e con la dicha jurisdición e justicia cevil e criminal alta e baxa e mero e mixto imperio que yo he e tengo en el dicho lugar e vasallos e de todas las dichas heredades e casas e solares e viñas e prados e montes e pastos e tierras e huertas e viñas e fuentes e otras alguas estantes e manantes e corrientes, e otras qualesquier cosas con todo lo sobredicho e cada cosa e parte dello que vos yo así vendo a vos el dicho Alfón Peres e a los dichos vuestros herederos e sucesores, e aquel o aquellos que de vos o dellos ovieren causa para agora e para siempre jamás de todas e qualesquier personas que agora o en algund tiempo vos lo contrarien o embargaren o quiera contrariar o embargar, de fecho o de derecho, en juicio o fuera del. $\mathrm{E}$ si en algund tiempo a vos o a los dichos vuestros herederos e sucesores o aquel o aquellos que de vos o dellos ovieren causa fuese puesta o movida questión o pleito o debate o contienda o molestación o turbación o impedimento alguno sobre lo que dicho es o sobre qualquier artículo o cosa o parte dello, en qualquier manera o por qualquier causa o razón que sea direta o indireta de fecho o de derecho en juicio o fuera de juicio, que lo faré

Hiingania, LIX/3, núm. 203 (1999) 823-855 
todo sano yo e mis sucesores a vos el dicho Alfón Peres e a los sucesores seamos tenudos e obligados. E yo me obligo por mi e por ellos de tomar e tomaremos el pleito o pleitos, e la vos e abtoría e defensión por vos e por los dichos vuestros sucesores e por qualquier dellos e por aquel o aquellos que de vos o dellos ovieren causa en qualquier manera e por qualquier causa e razón que sea, desde el día que por vos o por los dichos vuestros herederos e sucesores o por qualquier dellos o por otro en su nombre o vuestro fuere requerido yo o los dichos mis herederos e sucesores fasta quince días primeros seguientes so pena que vos pechen e pague los dichos setenta mill maravedís con la pena del doblo, e de vos pechar más todos los daños e menoscabos e costas a vos el dicho Alfón Peres e a vuestros herederos e sucesores, e aquel o aquellos que de vos o dellos ovieren causa por cada vez que fuere o veniere contra esto que dicho es o contra qualquier cosa o parte dello yo o mis herederos e sucesores en qualquier manera o por qualquier causa o razón que sea, e lo así non guardare e cumpliere todo como dicho es esto por pacto convencional e en nombre de interese que entre mi e vos es puesto e sosegado, e la dicha pena del doblo pagada o non que vos e los dichos mis herederos e sucesores todavía seamos tenudos e obligados a vos facer sano todo lo sobredicho e cada cosa e parte dello a vos e a vuestros herederos e sucesores e a otto qualquier o qualesquier que de vos o dellos ovieren causa en qualquier manera. E otrosí que todavía sea tenudo de tomar los dichos pleitos e voz e defensión e abtoría, e defenderlos e proseguirlos e facerlos alzar e quitar todo letigio e contrallamiento e toda turbación e molestación a nuestras propias costas e despensas de mi e de los dichos mis herederos e sucesores, en tal manera que vos el dicho Alfón Peres e vuestros herederos e sucesores e aquel o aquellos que de vos o dellos ovieren causa avades e podades aver todas las dichas heredades e casas e viñas e huertas e tierras e montes e pastos e vasallos e jurisdición e justicia cevil e criminal e mero mixto imperio e pechos e derechos e rentas con todo lo sobredicho e cada cosa e parte dello a paz e a salvo sin daño e sin contrario e sin impedimento e sin molestación nin embargo nin turbación alguna de fecho ni de derecho. E otrosí otorgo e me obligo por mi e por los dichos mis herederos e sucesores, so obligación que fago de mi e de todos mis bienes raices e muebles e de los dichos mis herederos e sucesores, que para agora e para siempre jamás yo he $\mathrm{e}$ ellos avrán por rato e grato e firme e valedero todo lo susodicho e cada cosa e parte e artículo dello, e todo lo que adelante en este contrabto será contenido, e que agora nin en algund tiempo non iré nin verné contra lo susodicho nin contra cosa e parte e artículo dello por lo contrariar o anular nin menguat en juicio ni fuera del, e si lo contrario ficiere que me non vala a mi nin a otro por mi en juicio nin fuera del de fecho nin de derecho en manera alguna nin por qualquier causa o razón que sea, ni nos oyan dello a mi nin a ellos nin sea recebido e ello non embargante que todo lo susodicho e cada cosa e parte e articulo dello finque e sea firme e estable e valedero para agora e para siempre jamás. E otorgo demás desto, que si todo lo que en esta carta de suso es contenido e en ella fará mención así non guardare e non cumpliere o non pudiere o non quisiere yo o los dichos mis herederos o contra qualquier cosa o parte de lo en esta 
carta contenido fuere o veniere en juicio o fuera del, yo o los dichos mis herederos o otro por mi o por ellos o otro qualquier por mi causa o suya dellos direte $o$ indirete de fecho o de derecho, en qualquier manera o por qualquier causa e razón que sea en qualquier tiempo que por ese mesmo fecho, cayan e vos peche en pena yo e los dichos mis herederos e sucesores a vos el dicho Alfonso Peres e a los dichos vuestros herederos e sucesores o aquel o aquellos que de vos o dellos ovieten causa en qualquier manera o por qualquier razón por cada vez que contra ello o contra qualquier cosa o artículo o parte dello vos fuere o veniere, como dicho es, en pena e por postura convencional que con vos puse, como dicho es, los dichos setenta mill maravedís con la dicha pena del doble e con los dichos daños e menoscabos e costas con el doblo que sea, para vos e para los dichos vuestros herederos e sucesores, e para aquel o aquellos que de vos o dellos ovieren causa, como dicho es. $E$ la dicha pena e penas del doblo del dicho principal e de las dichas costas e daños e menoscabos pagadas o non, que todavía seamos tenudos e obligados yo e los dichos mis herederos e sucesores de aver, e ayamos todo lo en esta carta contenido e cada cosa e parte e artículo dello por rato grato e forme e estable e valedero para agora e para siempre jamás.

E porque meior podades ser pagados e entregados vos el dicho Alfón Peres e los dichos vuestros herederos e sucesores, o el que de vos o dellos ovieren causa en qualquier manera e por qualquier razón de las dichas penas del dicho principal costado e daños e menoscabos, yo por mí e por los dichos mis herederos e sucesores me obligo e desde agora como de entonces aquel o aquellos que en la dicha pena cayere, de mi e de los dichos mis sucesores, e vos do e otorgo por mi e por ellos abtoridat e licencia con todo poder cumplido con libre e llenera administración, e a los alcaldes e jueces e justicias onde quier que esta carta fuere mostrada por vos el dicho Alfón Peres o a los dichos vuestros herederos e sucesores o por el que de vos o dellos o quien vuestro poder oficio aya, para que por vuestra propia o dellos o de qualquier dellos puedan entrar e tomar e ocupar e aprehender e tomen e entren e aprendan tales e tantos de nuestros bienes raices e muebles que valan tanto e más de la dicha pena del doblo del valor e quantía del dicho precio que la dicha vendida e de los dichos daños e costas e menoscabos con la dicha pena del doblo, en que vos cayere $o$ cayeren, e de cada cosa e parte dello, e que puedan facer e fagan entrega e esecución en los dichos bienes e los puedan vender e rematar e vendan e rematen sin almoneda o por almoneda sin licencia e sin abtoridat de jues e sin guardar la solepnidat formal o sustancial de las subastaciones, quel derecho en tal caso quiere, e sin guardar los términos e tiempo e plazo en que se debe facer la tal subastación e remate, e los puedan vender e vendan e rematen a buen barato o a malo, como quisierdes e por bien tovierdes, e vos entreguedes e se entreguen de lo que valieren, e fagan pago de las dichas penas e costas e daños e menoscabos con la dicha pena del doblo a vos mesmo e a los dichos vuestros herederos e sucesores, e aquel o aquellos que de vos o dellos ovieten causa, o quien vuestro poder oviere esto sin vos ser para ello presentes nin llamados nin requeridos ni oidos nin vencidos, todo esto bien así como por cosa que fuese

Hitpania, LIX/3, nứm. 203 (1999) 823-855 
judgada, que oviese primamente pasado por orden e forma de derecho sobre que fuese dada sentencia difinitiva consentida entre partes en juicio, de que non oviese nin pudiese haber apelación nin vista nin suplicación nin otro agravio nin nullidat nin otro remedio, en las quales dichas costas e daños e menoscabos quiero e consiento que seades creido vos e los dichos vuestros herederos, o aquel o aquellos que de vos o dellos ovieren causa, jurándolo llanamente en mi absencia fuera de juicio por ante notario o escribano público. E otorgo e quiero e consiento por mi e por los dichos mis herederos e sucesores de non registir yo nin ellos al tal alcalde o juez nin a otro que su mandado para ello oviere a la tal entrega e prenda nin a cosa alguna de lo sobredicho, que en esecución desta carta ficiere o mandare o facer a vos el dicho Alfón Peres, nin a los dichos vuestros herederos nin sucesores, nin aquel o aquellos que de vos o dellos ovieren causa, nin a otro vuestro procurador o suyo de vos o dellos que la dicha prenda e entrega e remate e vención de bienes e entrega e toma e posesión dellos quisiere facer o ficiere por resistencia alguna verbal nin actual de fecho nin de derecho, nin por otra qualquier causa o razón que yo aya, e los dichos mis herederos e sucesores en juicio e fuera del, e si lo ficiere o resistiere o ficieren o resistieren yo o ellos o otro por mi i por ellos o ellos o yo por otro o qualquier dellos en juicio o fuera del, en qualquier manera e por qualquier causa o razón que sea direte o indirete en juicio o fuera del, que nos non vala a mi nin a ellos, e que por ese mesmo fecho pueda yo e ellos e los que conmigo o con ellos lo resistieron ser invadidos e resistidos sin pena e sin calupnia alguna, e demás que por ese mesmo fecho de qualquier resistencia que así ficiere yo o los dichos mis herederos e sucesores en qualquier manera incurramos en la dicha pena del doblo de los dichos setenta mill maravedis del dicho precio de la dicha compra, e demás en la dicha pena del doblo e de las dichas costas e daños e menoscabos subastados e entregado e pagado vos el dicho Alfón Peres e los dichos vuestros herederos e sucesores o aquel o aquellos que de vos o dellos ovieren causa por la manera e forma susodichos, todavía que las dichas penàs del dicho principal e costas e daños e menoscabos pagadas o non siempre remanesca e quede firme e valedera la dicha vendida e todo lo en esta carta contenido e cada cosa e parte e artículo dello para agora e para siempre jamás, e pagat las dichas penas e costas e daños si en ellas cayere yo o los dichos mis herederos obligo a mi $\mathrm{e}$ a todos mis bienes raices e muebles avidos e por aver e de los dichos mis herederos e sucesores, e demás desto si e en qualquier manera e por qualquier causa e razón que sea para corroboración validación firmeza de todo lo sobredicho e de cada cosa e parte dello sea nescesario o cumplidero que'l rey nuestro señor lo confirme e aprueve esta dicha vendida e otogamiento e todo lo en esta carta contenido, por la presente omillmente suplico a su Alteza que por su carta lo aprueve e abtorice e confirme, e si nescesario es de nuevo la otorgue e mande e sobre todo lo en esta carta contenido e cada cosa e parte e artículo dello, e para lo mejor tener e guardar e cumplir e aver siempre por firme todo lo en esta carta contenido e cada cosa parte dello, yo por mi e por los dichos mis herederos e sucesores renuncio todas e quelesquier leyes e cánones encorporados o non en el cuerpo del derecho cevil e canónico, e todos otros fueros e derechos 
e constituciones sinodales e provinciales e ordenamientos e derechos municipales decretos encorporados o non en el cuerpo del derecho, e todo otro derecho canónico o cevil o estravagante escripto o non escripto, que en qualquier manera o por qualquier razón aproveche o pueda aprovechar a mi e a los dichos mis herederos e sucesores e a mi derecho e suyo e para ir o venir contra lo susodicho e contra cada cosa e articulo e parte dello, e de lo que adelante será escripto, e para me partir de lo en esta carta otorgado o de qualquier cosa o parte dello que non vala nin aproveche a mi nin a ellos, puesto que las dichas leyes e derechos e obstancias o qualquier dellas sean tales e de tal natura e condición que de derecho requieran especial renunciación o otra solepnidad alguna para se poder renunciar, e si las dichas renunciaciones non guardando de los dichos derechos o de qualquier dello quisiese usar en juicio o fuera del, que me non vala nin me sea recebido a mi nin a los dichos mis herederos e sucesores nin a otro por mi nin por ellos, e renuncio e parto de mi e de los dichos mis herederos e sucesores e de mi favor e ayuda e de mi e dellos toda razón e defensión e escepción e toda carta e mercet e previlleio del santo padre o del rey nuestro señor o de otro señor, ganados e por ganar, e de usos e costumbres e estilos e ferias e todo error e toda inorancia e toda anulación e plazo de conseio e de abogado e de todo traslado e toda sustancia e solepnidat e orden e todo beneficio de restitución in integrum e qualquier otro auxilio e beneficio ordinatio e extraordinario que a mi o a los dichos mis herederos e sucesores pertenesca o pertenecer pueda para ir o revocar o amenguar o contrastar todo lo susodicho en esta carta contenido e qualquier artículo o cosa e parte dello, e las leyes e derechos que fablan en razón del engaño de lo que es vendido o comprado por más o por menos allende de la meytad del justo e derecho precio, $\mathrm{e}$ renuncio por mi e por los dichos mis herederos e sucesores la ley e derecho que dice que se non entienda alguno renunciar lo que non sabe por tenunciación que faga, e los derechos que dicen que los caballeros que en algunos casos pueden pretender inorancia de derecho a ser testituidos, de las quales dichas leyes e derechos yo fui e so certificado por dotores e letrados juristas que me ficieron entender e saver las dichas leyes e derechos que yo avía e podía aver en mi favor, e la otra ley que dice que no se puede alguno renunciar salvo lo que sabe que le pertenece, e las leyes que dicen que los detechos que dan cierta forma $\mathrm{e}$ orden en los abtos e contrabtos non pueden ser renunciados, e las leyes e derecho que ponen cierta forma e solepnidad en las vendidas e donaciones que se han de facer de los bienes raices, e la ley que dice que los derechos e leyes prohibitivas non pueden ser renunciados, e la ley e derecho que dice que general renunciación non vala.

E porque esto sea firme e non venga en dubda otorgué esta carta ante Fernán Yanes de Galdo, escribano e notario público yusoescripto, al qual rogué que la escrebiese o ficiese escrebir e la sinase de su sino, e a los presentes que fuesen dello testigos, que fue fecha e otorgada en la villa de Monreal a ocho días del mes de marzo año del nascimiento de nuestro señor Jesucristo de mill e quatrocientos e treinta e seis años. Testigos que fueron presentes llamados e rogados para esto que dicho es Fernán Bravo alcayde del castillo de la dicha

Hipqania, LIX/3, nün. 203 (1999) 823-855 
Monreal, e Andrés de Villa Gómez, e Alvaro de Cornedo, e Lorenzo de Llanes escribano del rey, escuderos del dicho Martín de Luna, e otros, e yo el dicho Fernand Yanes de Galdo, escribano del dicho señor rey e su notario público en la su corte e en todos los sus regnos, a lo que dicho es presente fui en uno con los dichos testigos, e por ruego e otorgamiento del dicho Martín de Luna, que en mi presencia e de los dichos testigos recibió del dicho Arias de Tíneo en nombre del dicho Alfón Peres los dichos setenta mill maravedís en doblas de oro valadís e castellanas, que en mi presencia le fueron dadas, esta carta fise escribir en estas tres fojas de pargamino con esta en que va mi signo, e en fin de cada plana señalada de la rúbrica de mi nombre, e por ende fise aquí este mio signo a tal. Está signado en testimonio de verdad Fernand Yanes. 